\title{
LATENT HEAT OF FUSION OF ICE
}

\author{
By H. C. Dickinson, D. R. Harper 3d, and N. S. Osbome
}

CONTENTS

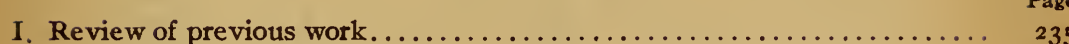

r. Determinations previous to $1870 \ldots \ldots \ldots \ldots \ldots \ldots \ldots \ldots .235$

2. Determinations subsequent to $1870 \ldots \ldots \ldots \ldots \ldots \ldots \ldots \ldots, 236$

II. Description of calorimetric methods and apparatus............... 238

r. Calorimetric methods........................ 238

2. Calorimeter.................................. 239

3. Electrical method............................... 242

4. Method of mixtures............................. 245

III. Materials........................................ ${ }^{245}$

IV. Manipulation of ice................................ 246

I. Manufacture of specimens.......................... 246

2. Precooling the specimens........................ 247

3. Temperature of cryostats ........................... 247

4. Handling the specimens........................... 248

5. Weighing the specimens......................... 250

6. Handling and weighing the mechanically dried specimens..... 250

V. Calculation of experimental results......................... $25 \mathrm{I}$

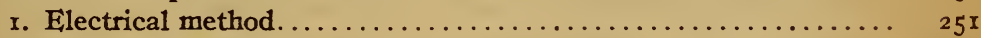

2. Method of mixtures.......................... 258

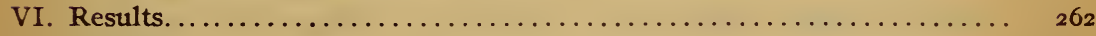

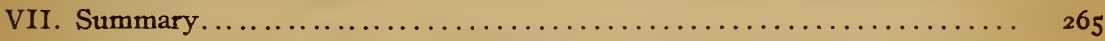

\section{REVIEW OF PREVIOUS WORK}

\section{DETERMINATIONS PREVIOUS TO 1870}

The determinations of the heat of fusion of ice up to the year I 870 have been reviewed by A. W. Smith, ${ }^{1}$ who prepared Table I giving a summary of the results:

There is great variation among the results of these earlier determinations, many of them are based on but few experiments, and there is little doubt that the experiments were carried out under conditions much less favorable than for those made more recently. 


\section{TABLE 1}

\begin{tabular}{|c|c|c|c|c|c|}
\hline \multirow{2}{*}{ Name } & \multirow{2}{*}{ Date } & \multirow{2}{*}{$\begin{array}{l}\text { Experi- } \\
\text { ments }\end{array}$} & \multirow{2}{*}{$\begin{array}{l}\text { Tempera- } \\
\text { ture range } \\
\text { of water }\end{array}$} & \multicolumn{2}{|c|}{ Heat of fusion } \\
\hline & & & & $\mathrm{cal}_{\mathbf{x}}$ & Btu \\
\hline Black $^{2}$... & 1762 & 2 & $80-0$ & 79.7 & 143.5 \\
\hline wilke........................ & ......... & 1 & $72-0$ & 72 & 129.6 \\
\hline Laplace and Lavolsier ${ }^{2}$... & 1780 & 2 & $100-0$ & 75 & 135.0 \\
\hline Provostaye and Desains 4. & 1843 & 17 & $24-10$ & 79.1 & 142.4 \\
\hline Regnault 5 .... & 1842 & 4 & $16-7$ & 79.24 & 142.6 \\
\hline Regnault...... & 1843 & 13 & $22-11$ & 79.06 & 142.3 \\
\hline Hess ${ }^{6} \ldots \ldots \ldots$ & 1848 & 40 & $19-7$ & 80.34 & 144.6 \\
\hline Person ${ }^{7} \ldots \ldots \ldots \ldots \ldots$ & 1850 & 6 & $16-5$ & 80.0 & 144.0 \\
\hline Bunsen $8 . . . \ldots \ldots \ldots$ & 1870 & 2 & $100-0$ & 80.02 & 144.0 \\
\hline
\end{tabular}

2 Lectures on Chemistry, Vol. I, p. rao.

${ }^{3}$ Mém. de l'Acad. des Sciences, 1780, p. 335; Oeuvres de Lavoisier I, p. 283.

${ }^{4}$ Ann. de Chim. et Phys., 8, p. 5 ; 1843 .

5 Ibid., 8, p. 19; 1843 .

- St. Petersburg Imp. Acad. Sci. Bull. de la Classe physico-mathématique, IX, p. 81; r85r.

${ }^{7}$ Ann. Chim. et Phys., 30, p. 73; 1850.

8 Phil. Mag. (41), p. 182; 1871 .

\section{DETERMINATIONS SUBSEQUENT TO 1870}

\section{Smith, Arthur W.9 (1903).}

As a result of eight experiments with the purest ice Swith found for the heat of fusion 334.21 joules per gram (weight $d$ in air against brass weights) based on the value $\mathrm{r} .434$ volts for the Clark cell at $15^{\circ} \mathrm{C}$. Expressed on the basis of the present electrical units ${ }^{10}$ and gram mass (i. e., weighings reduced to vacuo) this value becomes 333.24 joules per gram. If 4.187 joules are equivalent to one $15^{\circ}$ calorie (see p. 255 ), the above result reduces to 79.59 calories per gram.

Bogojawlensky ${ }^{11}$ (1904).

This experimenter used mercury as the calorimetric medium, employing the method of mixtures. The results of six experi-

\footnotetext{
- See note I, p. 235 .

10 The joule here used is defined by the ratio $\frac{e^{2}}{R} t$ where $e$ is expressed in international volts and $R$ is expressed in international ohms. The volt is based on the relation emf of Weston cell at $20^{\circ} \mathrm{C}=\mathrm{x} .0 \mathrm{0r} 83$ volts. The international ohm is the resistance offered to an unvarying electric current by a column of mercury at the temperature of melting ice, 14.4521 grams in mass, of a constant cross sectional area and of a length of ro6.300 centimeters.

"Schriften der Dorpater Naturforscher Gesellschaft, XIII; r904.
} 
ments on the heat of fusion of ice range from $79.4 \mathrm{I}$ to $79.9 \mathrm{I}$ with a mean value of $79.6 \mathrm{I}$ calories.

$\mathrm{He}$ also determined the specific heat of ice over the temperature range from $-85^{\circ} \mathrm{C}$ to $-5^{\circ} \cdot 5^{\mathrm{C}}$. For reduction of the heat of fusion determinations in which the range of temperature of the ice was from $-10^{\circ}$ to $0^{\circ}$, he used $0.5^{2}$ for the specific heat of ice.

Roth, W. A. ${ }^{12}$ (1908).

Roth has assembled the results of a number of determinations of the density of ice and deduced a value to use in calculating the heat of fusion of ice from the data of Behn ${ }^{13}$ and of Dieterici, ${ }^{14}$ both of whom used the Bunsen ice calorimeter.

The density determinations reviewed are as follows:

Bunsen (Ges. Abh., 3, p. 475), corrected value........... 0. 9168

Zakrzevski (Ann. der Phys. (3), 47, p. 155; 1892).......... .91658

Leduc (Compt. rend., 142, p. I49; I906)............... .9176

Nichols (Phys. Rev., 8, p. 2I; I899) $\ldots \ldots \ldots \ldots \ldots \ldots \ldots \ldots\left\{\begin{array}{c}.91603 \\ \text { to } \\ .91795\end{array}\right.$

Barnes (Phys. Rev., 13, p. 55; rgor)............... .91649

Vincent (Phys. Rev., 15, p. I29; I902)............... . 9160

${ }_{7}$ He states the mean, excluding Nichol's values, to be 0.9167 , but uses Bunsen's corrected value 0.9168 on the assumption that the conditions of producing the ice used in that density determination were nearly the same as those under which the ice calorimeter is generally used.

Applying this value to Behn's data Roth obtains for heat of fusion of ice $79.69 \mathrm{cal}_{15}$. similarly for Dieterici's data $79.60 \mathrm{cal}_{15^{\circ}}$.

A summary of the foregoing values giving the results of the most important determinations subsequent to 1870 is given in Table 2.

${ }^{12}$ Zs. für Phys. Chem., 63, p. 441; 1908.

${ }^{13}$ Ann. der Phys. (4), 16, p. 653; 1905.

14 Ibid., p. 593; 1905 .

$27647^{\circ}-14-6$ 
TABLE 2

\begin{tabular}{|c|c|c|c|c|}
\hline \multirow[b]{2}{*}{ Name } & \multirow[b]{2}{*}{ Date } & \multirow{2}{*}{$\begin{array}{l}\text { Experi- } \\
\text { ments }\end{array}$} & \multicolumn{2}{|c|}{ Heat of fusion } \\
\hline & & & $\begin{array}{l}\mathrm{cal}_{15^{\circ}} \\
\text { per gram }\end{array}$ & $\begin{array}{l}\text { Btu per } \\
\text { pound }\end{array}$ \\
\hline Smith.............. & 1903 & 8 & 1579.59 & 143.3 \\
\hline 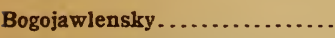 & 1904 & 6 & 79.61 & 143.3 \\
\hline Behn (calculated by Roth)...... & 1905 & 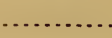 & 79.69 & 143.4 \\
\hline Dieterici (calculated by Roth).. & 1905 & & 79.60 & 143.3 \\
\hline Mean. . & & & 79.62 & 143.3 \\
\hline
\end{tabular}

${ }^{15}$ The determinations of Smith have been recalculated to the basis of the $15^{\circ}$ calorie and the gram mass. The remaining values are taken from the publications cited.

\section{DESCRIPTION OF CALORIMETRIC METHODS AND APPARATUS}

\section{CALORIMETRIC METHODS}

Two methods of calorimetry were employed in this work. In both methods the precision calorimeter described later was used, with calorimetric platinum resistance thermometers, water being the calorimetric medium. One was the well-known method of mixtures. The other was an electrical method somewhat resembling that of A. W. Smith, but differing from it in the use of water instead of oil as the calorimetric medium, in the form and size of ice specimens, and in the type of calorimeter and thermometers. The ice sample was put directly into the water and the approximate amount of energy required to melt the ice supplied electrically and measured, the small excess or deficiency being determined from the small rise or fall of temperature of the calorimeter. The temperature of the calorimeter water thus remained very constant, although a large amount of ice was used, and the corrections for heat interchange between calorimeter and surroundings were rendered small.

Although the electrical method as here carried out is the more precise because of the avoidance of large cooling corrections, nevertheless the ultimate accuracy with which the results can be expressed in terms of the calorie is limited by the accuracy with which the ratio of the joule to the calorie is known (at present 



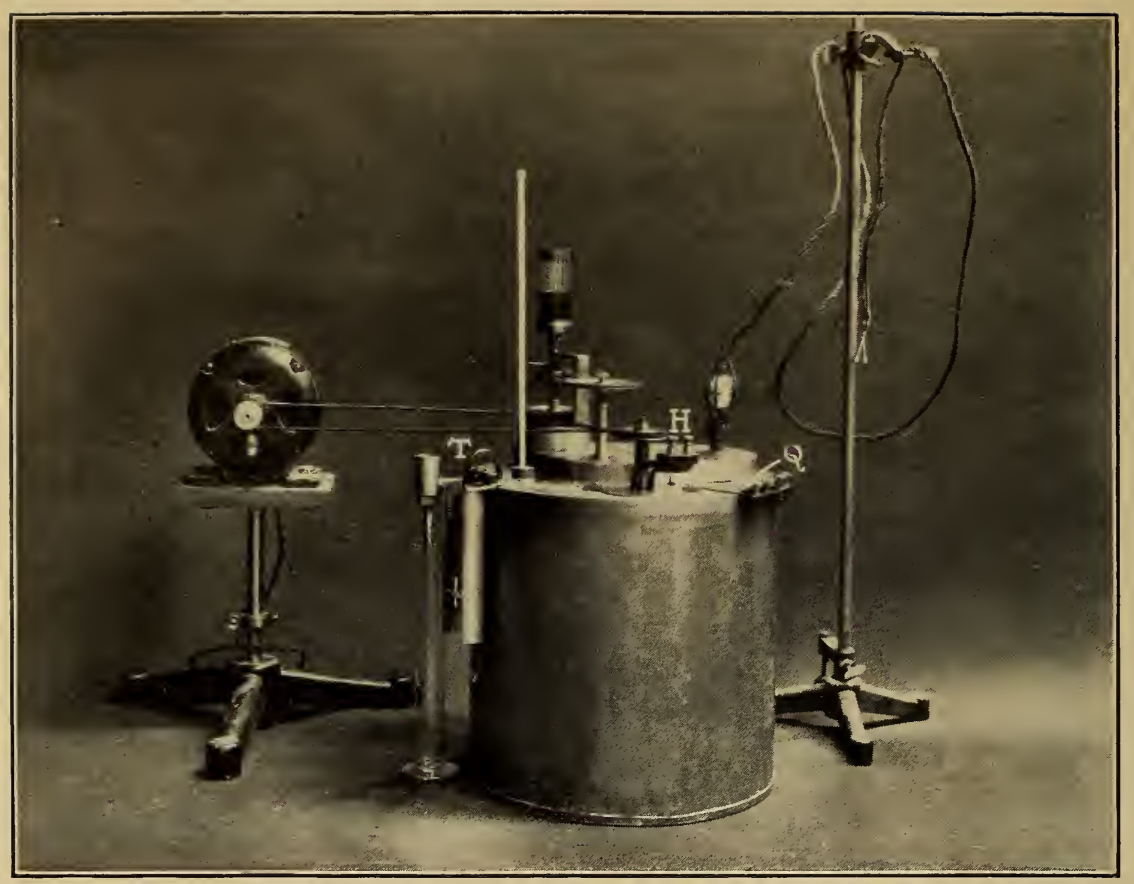

Fig. 1. -The calorimeter, assembled as used

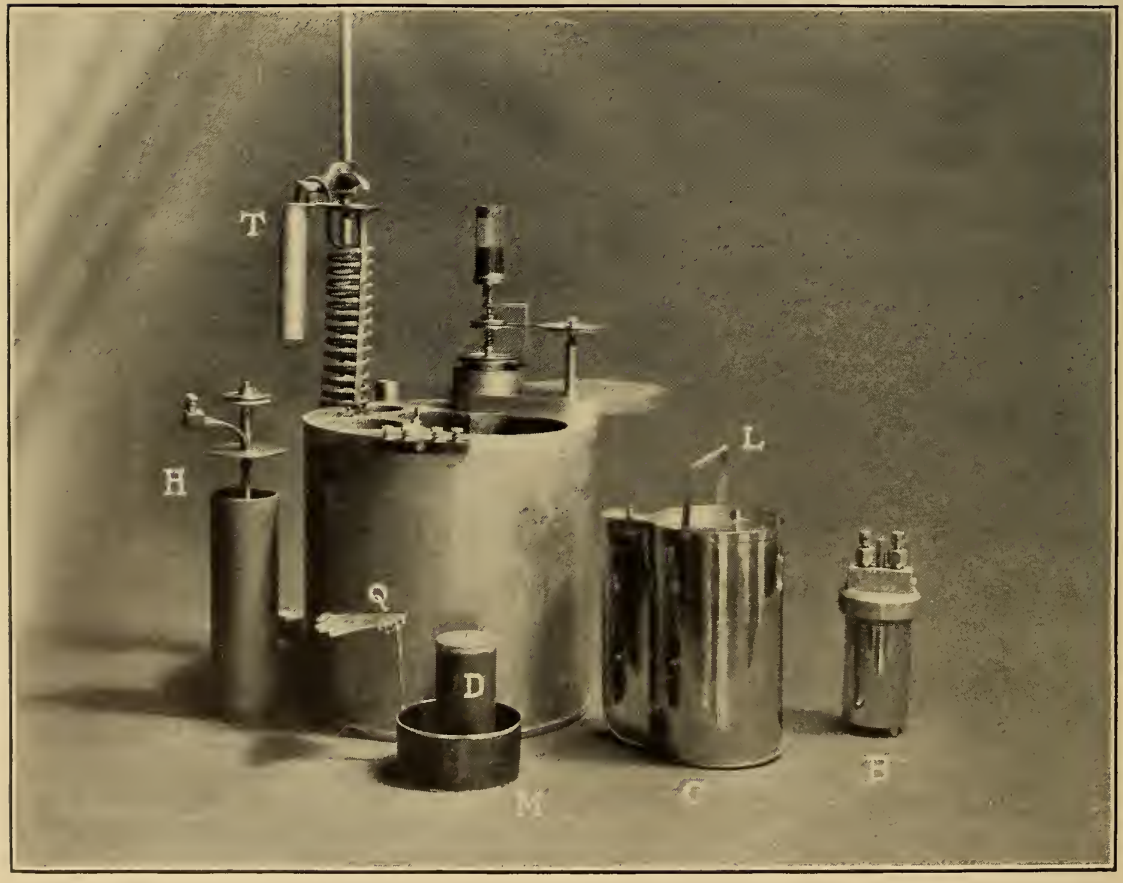

Fig. 2.-The calorimeter, detail of parts 
probably about I part in 2000); and for this reason the less precise method of mixtures was used as a direct and independent check.

The methods of manipulation are described more in detail later (pp. 242-245).

\section{CALORIMETER}

A calorimetric outfit originally developed for use with combustion bombs, but which has proved very well adapted to various calorimetric problems, was used without modifications for the present investigation. This calorimeter is described briefly below. A more detailed description of it will be communicated in the paper cited in footnote 23, p. 260.

Fig. I shows the jacket and the induction motor as they appear in use.

The stirrer mounted in the cover.automatically keeps water from the jacket circulating through the cover. The parabolic speed indicator mounted on top of this stirring shaft indicates the speed of stirring.

The current and potential leads to the electric heating coil are brought in across the top of the jacket inside of a closely fitting copper sheath $(Q)$, from which they are insulated by thin mica. The sheath is in close contact with the top of the jacket and is covered with a felt pad, so that the leads will be very nearly at the same temperature as the jacket.

Terminals to the heating coil in the jacket, and the upper part of the thermostat used when necessary to maintain a constant temperature in the jacket, are also shown, marked $(\mathrm{H})$ and $(\mathrm{T})$.

Fig. 2 shows the jacket with its cover turned aside to admit the calorimeter, illustrating how the cover is conveniently opened and closed without interfering with the stirring in the jacket. The calorimeter proper (C), with its cover and detachable handle $(\mathrm{L})$, and the heating coil (M) are shown at the right. The figure also includes a displacement buoy (D) and a combustion bomb (B) not used in these experiments. A heating coil $(\mathrm{H})$ for the jacket and the thermostat (T) appear at the left. 


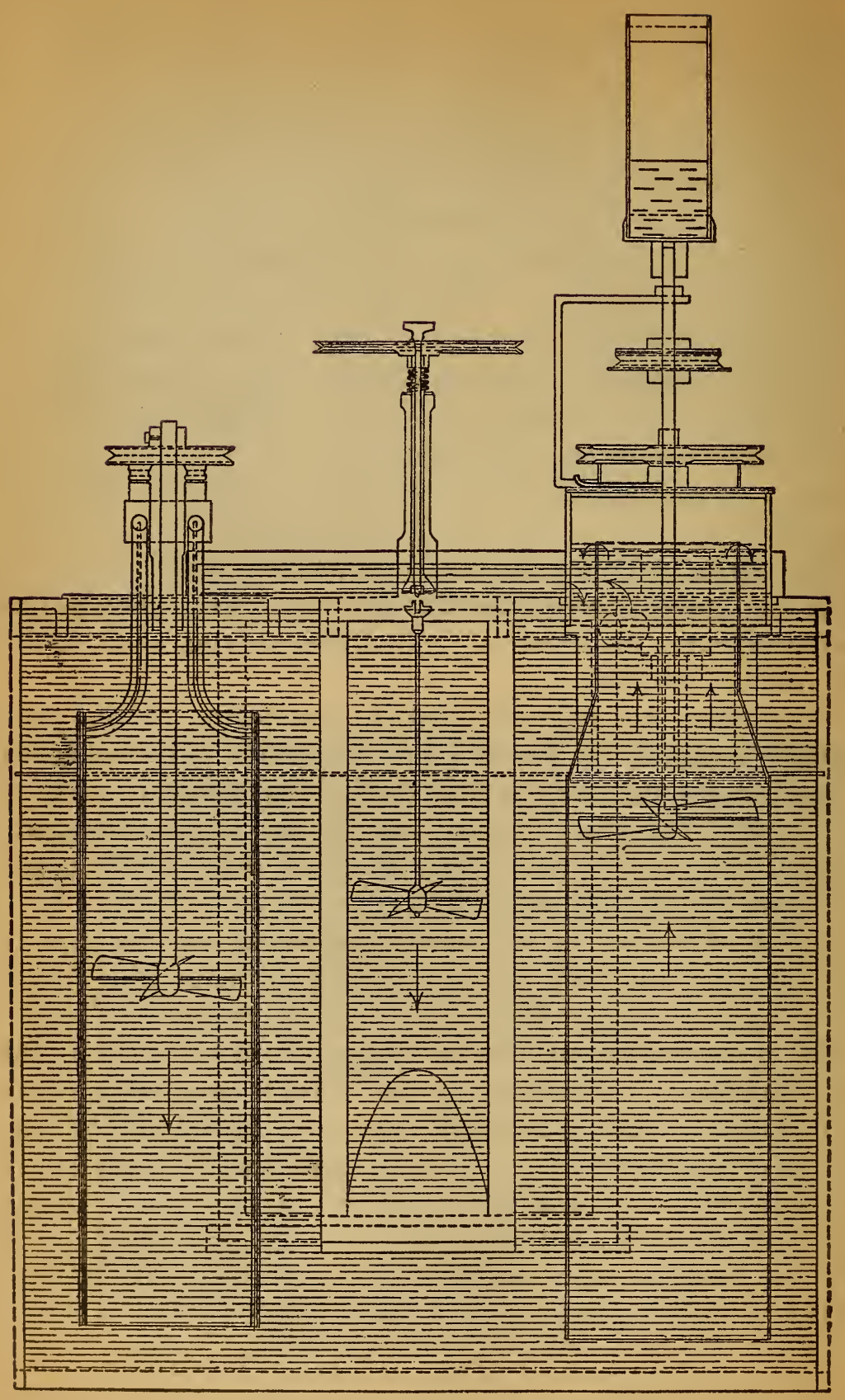

Fig. 3.-Section through calorimeter 
Fig. 3 shows the details of construction, representing a section through the three stirring shafts. The direction of circulation of the water is indicated by arrows. The main jacket stirrer draws water from the bottom of the jacket, sending part of it through the cover, which is at a higher level than that of the water in the jacket, and allowing the remainder to overflow into the upper part of the jacket. The method of connecting the calorimeter

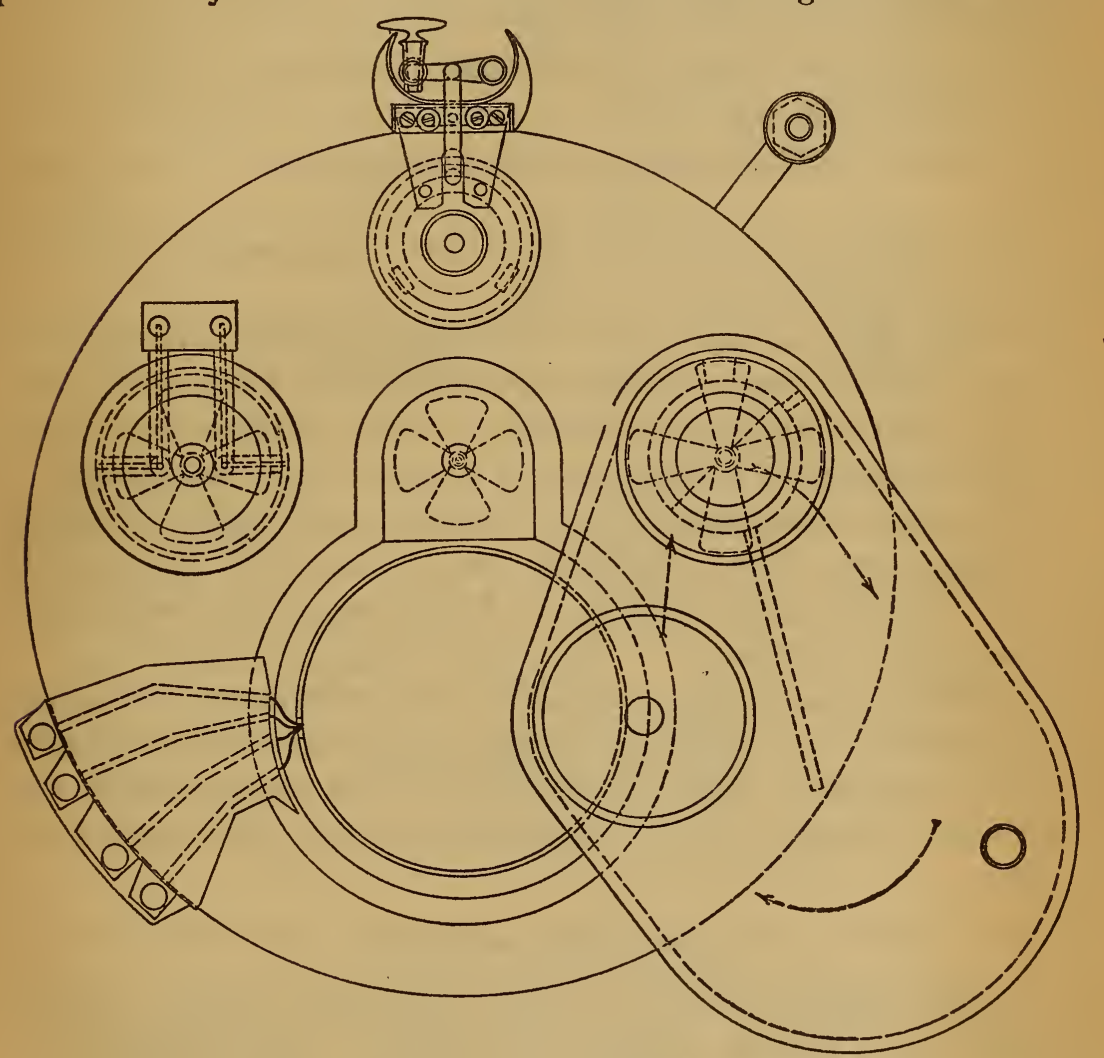

Fig. 4.-Plan of calorimeter

stirrer to its shaft is also shown. The energy supplied by the stirrer is due to fluid friction only, since there is no bearing within the calorimeter.

Fig. 4 is a plan of the instrument with the cover open.

There are thus realized (I) a well-stirred water calorimeter, (2) a very nearly uniform temperature jacket completely surround- 
ing it, and (3) the absence of any material of sensible heat capacity at an intermediate temperature which could affect the rate of cooling.

Constants of the calorimeter are as follows:

Water equivalent of metal container and all fixed metal parts as used, nearly all copper, 4I grams.

Water equivalent of heating coil, I I.5 grams.

Capacity of calorimeter, $3750 \mathrm{~cm}^{3}$.

Cooling constant $0: 000030$ per second per degree, or o. I I 5 calories per second per degree.

Variation of cooling constant with temperature, $0: 0000002$ per degree.

Power supplied by stirrer at 300 r.p.m., 0.05I watts; heats the calorimeter $0: 00000032$ per second.

Residual effect of the temperature of the room on the cooling constant, due to heat conducted by electrical lead wires, etc., past the jacket into the calorimeter, is o.oor 4 calories per second per degree difference in temperature between room and jacket.

The sensitive platinum resistance thermometers used to measure the temperature of the calorimeter water have been described in detail. ${ }^{16}$ As used they could be read to o:ooor $\mathrm{C}$ and were probably accurate to $0: 0003$.

The difference in temperature between the calorimeter and jacket was determined by means of a copper constantan thermoelement the two junctions of which in the form of flat plates rested, one against the bottom of the calorimeter and the other against the jacket.

\section{ELECTRICAL METHOD}

A steady supply of energy in the calorimeter heating coil was furnished by a storage battery of 80 volts. The current was so constant that the mean value could be determined to I part in 20000 during the period of five, six, or seven minutes for which it was usually employed. The measurement of the energy consisted of determinations of the current, the potential difference between the coil terminals, and the duration.

${ }^{16}$ Dickinson and Mueller: New Calorimetric Resistance Thermometers, this Bull.,9, p. 483; 19r3. 
The method of these measurements has been previously described. ${ }^{17}$ A diagram of the circuits is shown in Figure 5. The quick break switch (S) served to throw the current into either the heating coil (M) or a rheostat (R) of equal resistance outside the calorimeter, and simultaneously to record on the chronograph tape the time when the switch was thrown. Measurements of current and potential difference were taken alternately during the period of energy supply, using the switch $(\mathrm{K})$ which connects the potentiometer with either the o.I-ohm coil or the volt box. The heating coil was of such a resistance (Io ohms) that the

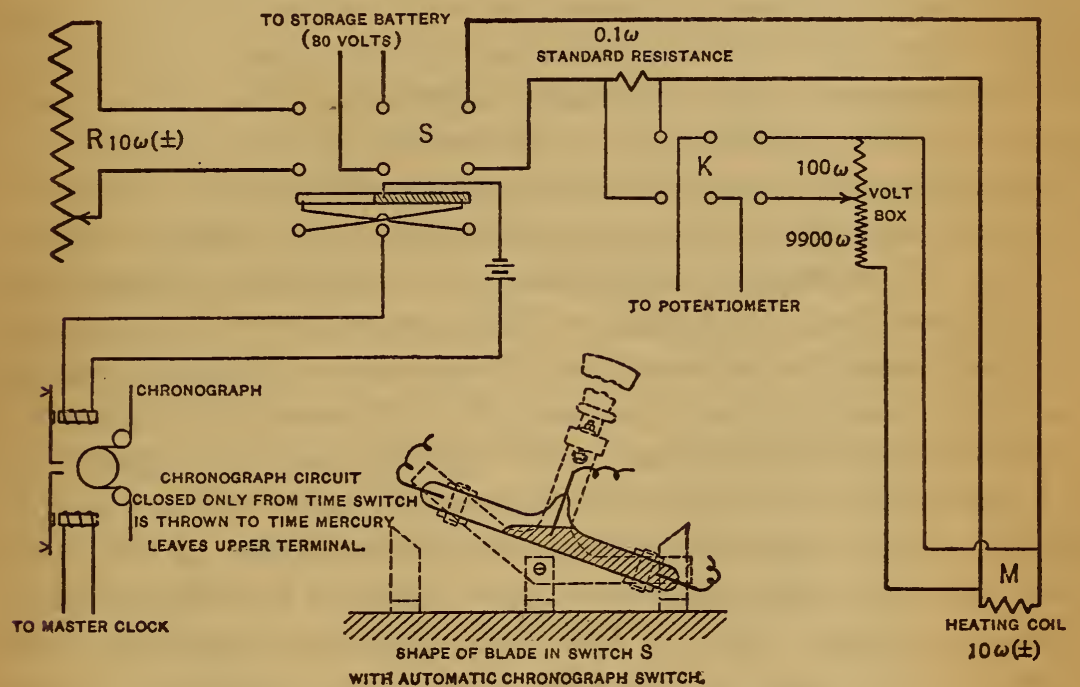

Fig. 5.-Diagram of circuits for electrical method

potentiometer settings were very nearly the same for both measurements. The mean current, mean potential difference and the time, the product of which measures the total energy, were each measured to better than I part in 20000 .

In this method the difference in temperature of the calorimeter water before and after melting the ice was seldom more than $0:_{2} \mathrm{C}$. However, during the period of melting, on account of the more rapid melting of the ice sample when first introduced, the temperature of the calorimeter fell during the earlier part and rose later. (See Fig. 9.) The shape of the ice sample was chosen with a

\footnotetext{
179
} 
view to making the rate of melting as uniform as possible. (See p. 246.)

The mean temperature difference between calorimeter and jacket was obtained by observations on the thermoelement at halfminute intervals.

The procedure for a determination was as follows: The ice specimen of suitable shape and size was weighed approximately to determine the amount of water necessary to accommodate it in the calorimeter. This amount of water was weighed into the calorimeter, the calorimeter was put in place in the jacket, and the heating coil placed in the calorimeter. The jacket cover was then closed, the thermometer inserted, the stirrer started, and the temperature of the calorimeter adjusted to that of the jacket by use of the thermocouple. Meanwhile the ice specimen was accurately weighed and the heating current adjusted to supply the required amount of energy when flowing for a suitable integral number of minutes, so determined by preliminary experiments as to cause least variation in temperature of the calorimeter. To avoid error due to the contact device on the standard clock, the current was always thrown on and off at the same break second.

After several observations of the temperature of the calorimeter, the operations of opening and closing the jacket cover were performed in the same manner as when introducing an ice specimen and the temperature was again observed in order to determine the thermal effect of opening. This was found to be from $0: 001$ to $0: 004$ and to vary with surrounding conditions, so that as a precaution it was observed for nearly every determination.

With all in readiness the cover was opened, the specimen introduced as described later (p. 248), the heating current thrown on, the cover closed, stirrer started, and thermometer reinserted, all these manipulations taking place according to a prearranged program. One observer immediately began to take the potentiometer readings and the other took frequent readings on the thermocouple for the temperature difference between calorimeter and jacket until the temperature again became steady. Then another accurate temperature determination was made by means of several observations with the resistance thermometer. 
The small change in temperature of the calorimeter, the heat loss or gain to the jacket, and the effect of opening the calorimeter are treated as corrections to the total measured energy supplied electrically.

The cooling constant, effect of stirring and lead conduction, and thermocouple sensibility were frequently determined, although the corrections due to these factors proved so small as to render this precaution almost unnecessary.

\section{METHOD OF MIXTURES}

In the determinations by the method of mixtures the heating coil and the apparatus for measurement of electric energy were not required. In other respects the apparatus and experimental procedure were similar to those of the electrical method except that, owing to the desirability of keeping the cooling correction within suitable limits, smaller specimens of ice (roo to 200 grams) were found better suited to the method of mixtures.

The initial temperature of the calorimeter was made slightly lower than that of the jacket and the final temperature was from $3^{\circ}$ to $6^{\circ}$ lower, depending upon the amount of ice melted. The temperature difference between jacket and calorimeter during the experiment was in some cases determined by the thermocouple and in others by the resistance thermometer. The cooling corrections in this method were usually of the order of 2 per cent of the total heat in question.

\section{MATERIALS}

The ice used for most of the determinations was commercial artificial can or plate ice frozen from city filtered water which was distilled and boiled before freezing. The samples were especially selected for clearness and freedom from bubbles. The can ice was the same as that used regularly at the Bureau of Standards for determining ice points of thermometers. Frequent conductivity tests showed it to be very pure.

For purposes of comparison, determinations were made on ice from several other sources. Natural ice, about one foot thick, 
from Maine was used in preparing the specimens for five of the experiments. This ice was not very clear in appearance, containing many air bubbles, but conductivity tests showed that it was nearly as pure as double-distilled water.

A number of specimens were prepared from double-distilled water frozen in a tin-lined cylindrical copper vessel constructed to give samples of the required shape and size. The water was either first boiled to remove dissolved air and then frozen as quickly as possible or else the vessel was evacuated and the water frozen while the air was excluded. These processes were not entirely successful in producing perfectly clear ice, although ice of a very good degree of clearness was obtained.

One sample was frozen from water purposely contaminated with a mixture of ammonia, sodium chloride and calcium chloride, to the extent of about $\mathrm{I}$ part in 1000.

\section{MANIPULATION OF ICE}

\section{MANUFACTURE OF SPECIMENS}

In order to secure greater uniformity in the rate of melting than would obtain with solid blocks, specimens were made in the shape of hollow circular cylinders of about $9.5 \mathrm{~cm}$ outside diameter and from 2 to $4 \mathrm{~cm}$ inside diameter. The lengths varied from about $3 \mathrm{~cm}$ to $9.5 \mathrm{~cm}$. Fig. 6 shows a photograph of two of the specimens in the copper holders.

In making the specimens from commercial ice a rectangular piece was first sawed from the selected solid block. By planing with an ordinary ice shaver this was worked down to a cylinder of the required diameter, which was then sawed into the lengths desired. A hole was drilled through the principal axis of each specimen and enlarged to proper size by running tap water. A few of the specimens, which were dried mechanically at the melting point, were left solid. The ice which was frozen in the cylindrical copper can was obtained in the form of a hollow cylinder and required only to be sawed into the desired lengths. 

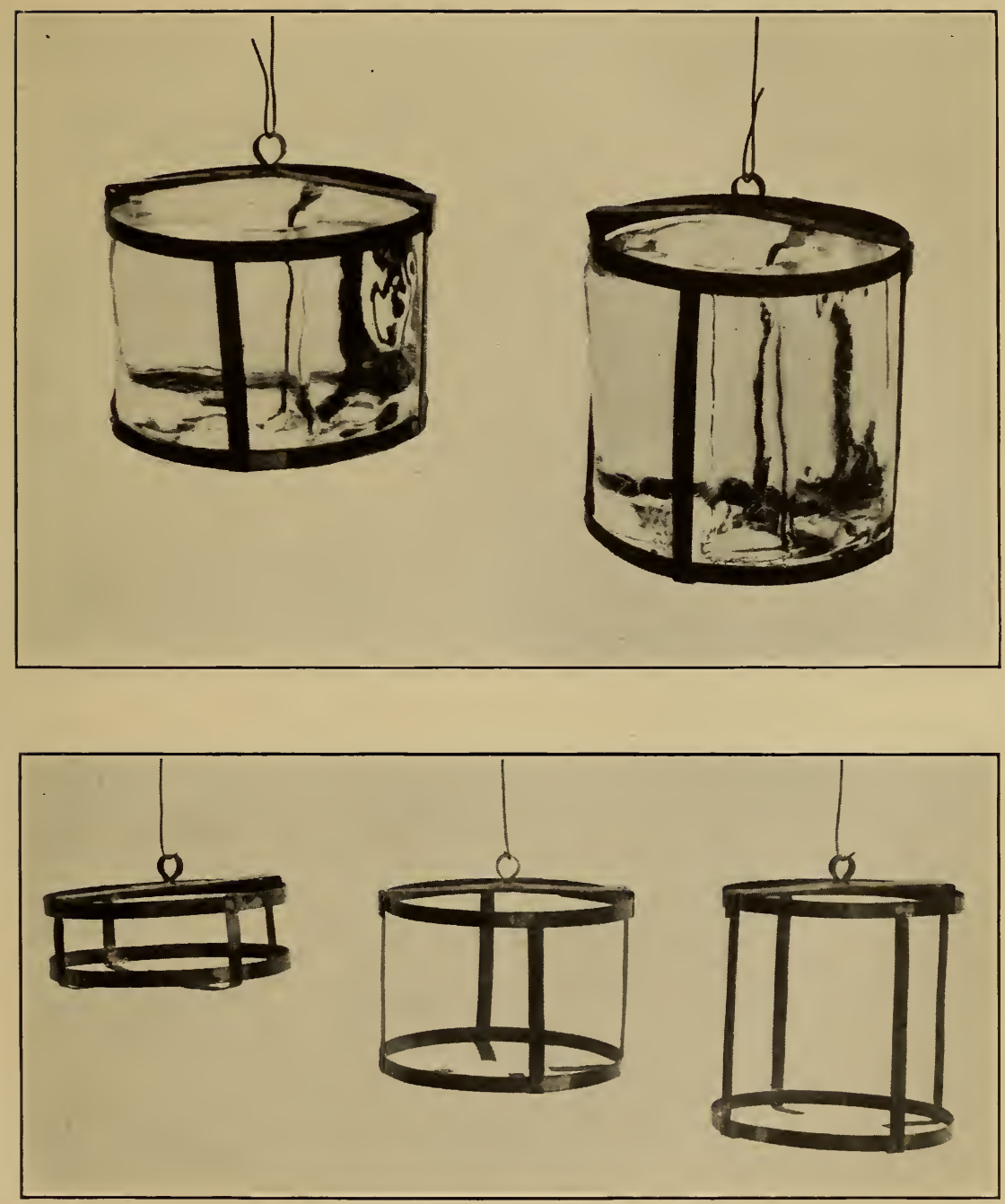

Fig. 6.-Ice specimens, showing hollow cylindrical shape employed. Copper holders for the specimens 



\section{PRECOOLING THE SPECIMENS}

\section{DESCRIPTION OF CRYOSTATS}

In order to insure the dryness of the ice, except for the few specimens which were mechanically dried, and to bring the specimens to a definite temperature before the determination, two cryostats were used. One of these cryostats is shown in section in Fig. 7. The cylindrical copper vessel (A) is supported within a larger cylindrical vessel externally insulated by cork chips (C) within a wooden box. The space (B) between the two vessels is packed solidly with a cryohydric mixture of finely shaved ice, a suitable salt, and saturated aqueous solution of the salt. The top of the vessel (A) is covered with a removable vessel $(\mathrm{E})$, also filled with the cryohydric mixture. A tube extends through this cover to admit the suspension hook (G) used in weighing the specimens. The insulating covers $(\mathrm{D})$ and $(\mathrm{F})$ are removable.

The other cryostat was similar in construction, but had somewhat thicker insulation and lacked the central tube in the removable cover. The one is called the weighing cryostat and the other the storage cryostat. Three specimens could be accommodated in the storage cryostat and two in the weighing one, as shown.

For a day's series of determinations, the specimens were placed in the cryostats the previous afternoon, allowing at least I 6 hours for the specimens to come to a constant temperature before the determinations were made. The salts employed were boric acid and magnesium sulphate, U.S.P. purity.

\section{TEMPERATURE OF CRYOSTATS}

For determining the temperature attained in the cryostats, surveys by means of copper-constantan thermoelements were made. Single junctions at various points on the interior wall of the cryostat were each connected to a reference junction kept in ice. The thermo electromotive force was measured by a potentiometer, and although the sensibility was a fraction of a microvolt, the accuracy of the temperatures may not have been better than $0: 05 \mathrm{C}$, on account of the fact that the thermoelements were not rigidly inclosed and possibly not always immersed to the same depth. 
The temperature uniformity of the interior walls was found to be better in the storage cryostat than in the weighing one, both as to vertical distribution and constancy with time.

Further test as to the temperature assumed by an ice specimen in the cryostats was made by inserting four junctions directly into holes drilled in the ice. The holes were then filled with water, plugged up, the water frozen and the specimen placed in the cryostat as when preparing for a determination. It was found that a specimen thus prepared and put in the cryostat at $4 \mathrm{p} . \mathrm{m}$. attained by 9 a. m. next day an equilibrium temperature condition within the accuracy of the tests referred to above.

Transfer of the specimen from the storage cryostat to the weighing one produced a small rise of temperature which persisted while the specimen was kept in the weighing cryostat. The change is therefore doubtless due to the slightly higher average temperature of this cryostat, owing partly to the smaller cover vessel and partly to the central tube through the cover. As a result of these surveys the temperature of the specimens either cooled in the storage cryostat with the boric acid mixture and then transferred to the weighing cryostat, or else cooled in the later was found to be $-0: 72 \mathrm{C}$. With the magnesium sulphate mixture the observations showed that the temperature of the specimen should be taken as $-3: 78 \mathrm{C}$.

\section{HANDLING THE SPECIMENS}

For handling the specimens, when packing them in the cryostats, weighing, and transferring to the calorimeter, they were inclosed in holders made of sheet copper, as shown in Fig. 6. The bar across the top which carries the supporting ring is detachable for inserting the specimen. Each was provided with a loop of linen thread passed through the ring, by means of which the specimen could be transferred to the weighing cryostat and then lifted until the suspension hook was engaged in the ring. The thread was then cut and removed, leaving the specimen hanging, as shown in Fig. 7. After weighing, the specimen was transferred to the calorimeter by lifting the cover vessel, suspension hook, and specimen together from the cryostat, carefully lower- 
Dickinson,Harper.] Latent Heat of Fusion of Ice
Osborne

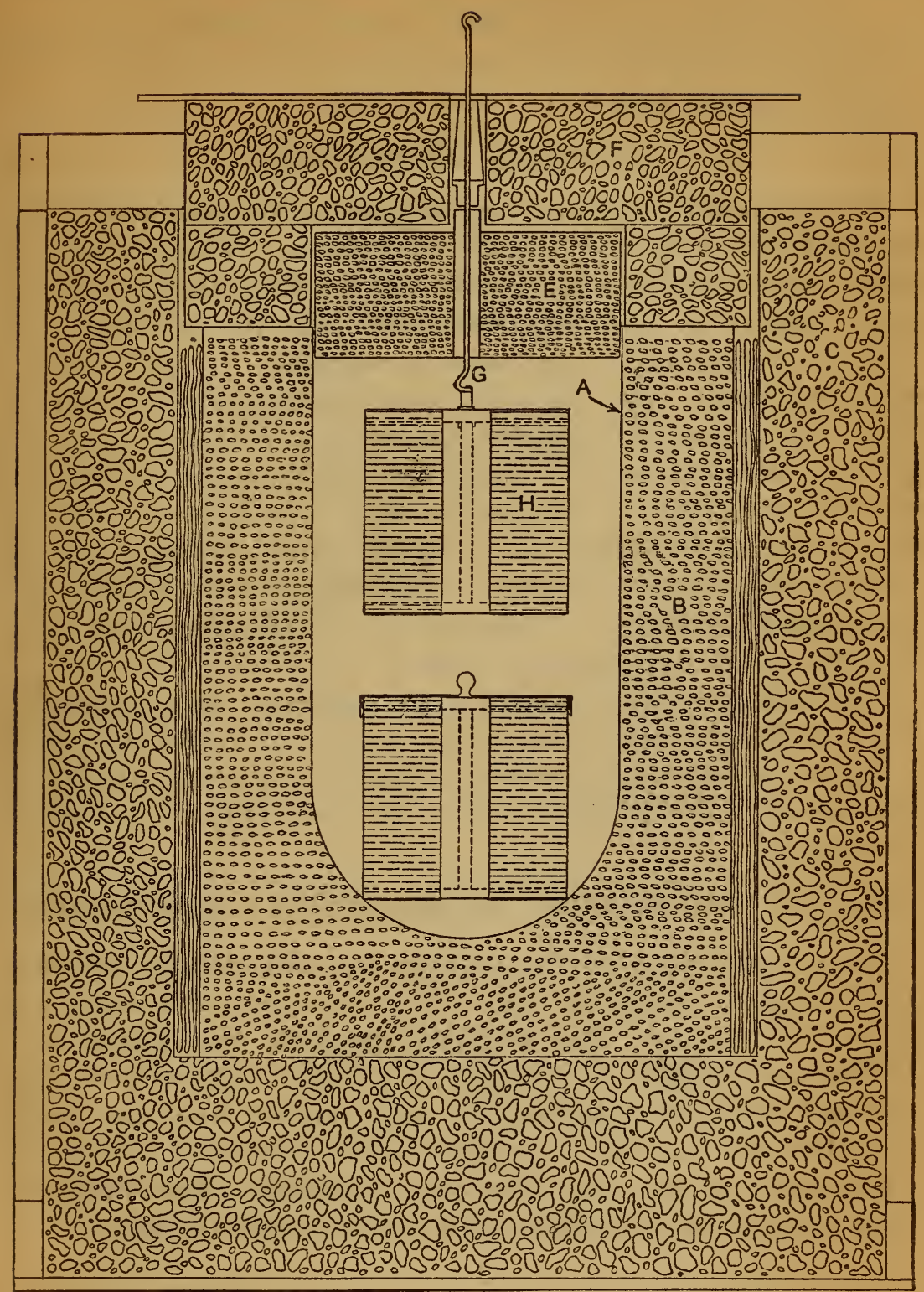

Fig. 7.-Section through cryostat, by use of which ice specimens were brought to a fixed, known temperature 
ing the specimen into the open calorimeter, and then detaching the hook, leaving the specimen immersed in the water. This transfer required only two to three seconds.

\section{WEIGHING THE SPECIMENS}

The precooled specimens were weighed while suspended in the cryostat (Fig. 7) placed beneath the balance. A suspension wire from a hook under the left balance pan led down through the balance support to the hook extending into the cryostat. The method of substitution was used in weighing. A fixed counterpoise was kept upon the right pan throughout the weighing. With the specimen suspended the weights necessary upon the left pan were determined. After the specimen was removed for the determination, the suspension alone was balanced, the difference between this and the previous balance reading giving the weight of specimen and holder. The weights of the holders were determined separately. Correction for air buoyancy was made, thus the results are expressed in mass units.

The balance used in weighing ice specimens was constructed by $\mathrm{A}$. Collot, of Paris. It was air damped and read directly to I $\mathrm{mg}$ by means of a microscope sighted on a scale attached to the pointer. The results for mass are given only to the nearest centigram.

\section{HANDLING AND WEIGHING THE MECHANICALLY DRIED SPECIMENS}

These specimens, cut in the form of solid circular cylinders, were wrapped loosely in linen cloths to absorb the water produced by melting. The wrapped specimen was placed in a beaker and weighed. By means of a copper harness previously fastened about the specimen, it was removed from the beaker and after removing the wrappings the ice was placed in the open calorimeter as with the precooled specimens. "The wrappings were returned to the beaker and weighed to give the tare. 


\section{CALCULATION OF EXPERIMENTAL RESULTS}

\section{ELECTRICAL METHOD}

The method of making the calculations will be explained with reference to the sample laboratory record forming Fig. 8: $t_{1}$ and $t_{2}$ are two arbitrarily selected times for which it is desired to determine as exactly as possible the corresponding calorimeter temperatures, the former before the ice is introduced, the latter soon after the ice has melted when equilibrium has again been established.

In the example $t_{1}$ is taken as $\mathrm{II}-\mathrm{OI}-44$. The data obtained previous to this instant serve to determine the temperature at $t_{1}$ which is measured by the resistance $\left(R_{1}\right.$ cor. $)$ of the platinum thermometer. These data include a series of thermometer readings from $10-58$ to $\mathrm{II}-\mathrm{OI}$ which are extrapolated to II-OI-44 and corrected for the temperature change of the calorimeter which results from opening it (at about $I I-O I-30$ ) to receive the ice. They also include the readings appertaining to a "blank" opening and closing, similar in all respects to the one just mentioned, from which the correction for opening is computed. The steps of the process are set forth on the sample record, and the condition at $t_{1}=\mathrm{II}-\mathrm{OI}-44$ may be thus recapitulated: The calorimeter is open ready to receive the ice and the supply of electrical energy, and its temperature, corrected for everything including the effect of opening, corresponds to the value $R_{1 \text { cor. }}=26.68404$.

Similarly, choosing $t_{2}$ as $\mathrm{II}-09-00$, the data determined after this time fix $R_{2}$ cor. $=26.69160$. This is obtained by extrapolation of the series of readings from I I II to I I-2O.

Let us now consider the heat changes in the calorimeter system between II $-0 \mathrm{I}-44$ and II-09-00. There are five possible sources of energy supply to the calorimeter:

(I) Electric heating coil.

(2) Radiation, convection, etc., from jacket.

(3) Stirrer.

(4) Heat conduction through the jacket from the room (along the resistance thermometer leads, etc.).

(5) Measuring current in the thermometer. 


\section{Beppartment of Crammurex and Tahne \\ BUREAU OF STANDARDS \\ 政}

Observers HCD DRH NSO Computed by $D R H$

CALORIMETER RECORD

Date Feb. 13,1813

Expt. No. 1

\begin{tabular}{|c|c|c|c|c|c|c|c|}
\hline & & & & TIME & DIF. & RESISTANCE & MOTES \\
\hline $11-01-00$ & \multicolumn{3}{|c|}{ (Effect of opening) } & $10-54$ & 2 & 26. 68431 & Br. BS7481 at $30^{\circ} \mathrm{C}$ \\
\hline $01-44$ & $10-56$ & \multicolumn{2}{|c|}{26.68436} & 55 & 3 & 8433 & Callb. of 1-27-13 \\
\hline $44 \mathrm{sec}$. & \multicolumn{2}{|l|}{$2 \mathrm{~min}$. rise $=$} & 4 & 56 & & 8436 & Ratio $100 \mathbf{R}$ \\
\hline 0.00002 per min. & \multicolumn{3}{|r|}{.68440} & open & ed ca & lorimeter & Therm. B. S. 4727 \\
\hline+2 & \multicolumn{2}{|l|}{$10-58$} & .68418 & 58 & & 26.68418 & 4.5 mill'amps. \\
\hline & \multicolumn{3}{|c|}{ Cooled by opening .00022} & 59 & & 8421 & \\
\hline$\frac{26.68424}{-\quad 22 \text { (opening) }}$ & \multicolumn{3}{|l|}{$(\approx 0.0022)$} & $11-00$ & & 8422 & \\
\hline $\mathbf{R}_{1000.2} 26.68404$ & \multirow{2}{*}{\multicolumn{3}{|c|}{ Cell No. 343 (1.01824 volts) }} & 01 & & 8424 & \\
\hline \multirow{2}{*}{$\begin{array}{|lr|}\text { Pot. No. } & \text { L \& N } 3314 \\
\text { Volt Box No. } & \text { Wolff } 4898 \\
\end{array}$} & & & & & & & \\
\hline & \multicolumn{3}{|c|}{ Std. Res. No. L \& N 7354} & 01-49 & & Ice in & \\
\hline Temp. $16^{\circ} 4$ & Temp. 1698 & & & & & & (Thermocouplo) \\
\hline $11-02-30$ & $11-03$ & & .67578 & $11-02$ & & & $8-15.0$ \\
\hline 37 & $04-30$ & & 76 & -30 & & & 17.2 \\
\hline $05-30$ & 06 & & 75 & 03 & & & 20.5 \\
\hline 31 & & & & & & & 22.8 \\
\hline & & & & 04 & & & 22.8 \\
\hline .67535 & Mean & & .67576 & & & & 22.8 \\
\hline Pot. Cor. & Pot. Cor. & & 3 & 05 & & & 21.2 \\
\hline Vitb. fctr. & Res. Std. & & 51 & & & & 21.2 \\
\hline & Vlt. bx. cur. & - & 67 & 06 & & & 20.2 \\
\hline & & & & & & & 18.6 \\
\hline 67.535 & Amperes & & 6.7455 & 07 & & & 16.5 \\
\hline Resistance & Power & & 455.56 & & & & 16.1 \\
\hline & & & & 08 & & & 14.7 \\
\hline \begin{tabular}{l|l|l|} 
on $11-01-44.45$ & Time 359. \\
\end{tabular} & 92 Energy 1 & 63964. & (joules) & & & & 15.0 \\
\hline $07-44.37$ & $=\quad 39$ & $160.2(c$ & $\left(a l_{15}\right)$ & 09 & & & 14.9 \\
\hline $11-11-00$ & Calorimeter & No. 76 & 603 & 09-15 & & & 14.90 and steady \\
\hline $09-00$ & Gross weigh & & 3700.0 & & & & \\
\hline $2 \mathrm{~min}$ & Cor. to wts. & - & 0.2 & $11-11$ & & 26.69161 & $18.65=$ average \\
\hline$r_{2} \quad 0.000007$ per min & Tare & - & 409.5 & 12 & & 9162 & 15.00 (zero setting) \\
\hline $\mathrm{rgdt}-$ & Buoyancy cor & . $\quad+$ & 3.5 & 13 & & 9162 & $3.65 \mathrm{~cm}=$ av. defl. \\
\hline $\begin{array}{ll}\mathbf{R}_{2} & 26.69161 \\
\end{array}$ & Mass water & & 3293.8 & 14 & & 9163 & during $7 \mathrm{~min}$. \\
\hline $\mathbf{R}_{200 r .} 26.69160(\approx 15912)$ & Heat cap. (15 & & 3294. & & & & \\
\hline $\mathbf{R}_{1000 .} 26.68404$ & Calorimeter, & etc. & 38. & 20 & & 9167 & $(1 \mathrm{~cm} \approx 09145)$ \\
\hline .00756 & Heater & & 12. & & & & $3.65 \mathrm{~cm}=0=0953$ \\
\hline$B d g \pm$ & Total Eeat c & & 3344 & & & & \\
\hline & & & & Calo & rimet & er gains 0.1 & 15 cal. per sec. \\
\hline .00756 & Ice-Sample N & $0.66 \mathrm{in}$ & holder $\mathrm{F}$ & when 1 & cool & er than jack & 0953 \\
\hline $\mathbf{K}_{26.587}$ & BOOM TEMP. & JAG & KET & below & on ave & rage) for 420 & sec. \\
\hline 090760 & THERM.(COR.) & THERM & 1. 4190 & & & Receive & s 25.4 calories \\
\hline Equiv. (M) 3344 & Time Temp. & Time & Temp. & & & & \\
\hline Mn. Tmp. $15: 08$ & $13.9^{\circ}$ & 10.56 & $15: 196$ & Stirre & r sup & plies $0.75 \mathrm{cal}$ & per min. for 7 min. \\
\hline $3344 \times 0.0760=(-) \quad 254.1$ & & 11.09 & .188 & & & $5.3 \mathrm{c}$ & al. \\
\hline Cooling enrr. & 13.5 & 11.20 & .181 & & & & \\
\hline Stirrer & & & & & & & \\
\hline Electric heater & & & & & & & \\
\hline
\end{tabular}

38937. cal 15 to melt sample 66 , heating it and holder $F$ to $15: 12$

Fig. 8. - Laboratory record of an experiment by the electrical method 
Record for ice samples gives for No. 66

Initial temperature $-0^{\circ} .72$. Weighed in holder $\mathrm{F}$

Readings of Balance, $271.646+$ sample + holder + suspension = counterpoise (grams)

$445.976=$ weight of sample and holder (in air at $0^{\circ}$ )

$37.873=$ weight of holder

$408.103=$ weight of sample (in air at $0^{\circ}$ )

.51 (Buoyancy correction)

$408.61=$ Mass of Ice

Holder F

Weight Mean spec. ht. Temp. Change $37.9 \mathrm{~g} \quad 0.92 \quad-0^{\circ} .7$ to $+15^{\circ} .1$ $37.9 \times 0.92 \times 15.8=55$

(continued from Fig. 8)

$$
37.9 \times 0.92 \times 15.8=55
$$$$
38937 \text { (Ice and holder) }
$$$$
55 \text { (holder) }
$$$$
38882 \text { (Ice, 408.61g) }
$$

$95.15 \mathrm{cal}$ per gram

To heat $1 \mathrm{~g}$ water from $0^{\circ}$ to $15^{\circ} .12$ $15.17 \mathrm{cal}$

\subsection{8}

To heat $1 \mathrm{~g}$ ice from $-0^{\circ} .72$ to $0^{\circ}$

$79.61=$ Latent heat of Fusion $27647^{\circ}-14-7$ 
Some of these sources may be sinks, which can readily be taken into account by the use of the negative sign when necessary.

The energy so supplied may go to-

(6) Heating the ice to $0^{\circ}$, melting it and heating the resulting water to the final calorimeter temperature.

(7) Heating the copper holder of the ice specimen.

(8) Raising the temperature of the calorimeter.

(9) Evaporating water from the calorimeter.

The last two may be negative, depending on the conditions. No ambiguity arises, however, from the more or less arbitrary division which has been made. It is assumed that these nine processes alone take place, and that when they have all been considered, all the energy changes will be accounted for. It may be shown that (4), (5), and (9) were probably less than one tenthousandth part of (I) in all of the experiments. They were therefore neglected in making the reductions. The remaining six terms are computed in full on the records pertaining to each experiment.

Lead Conduction (4).-The calorimeter and jacket were usually a degree or two warmer than the room, but never more than $4^{\circ}$. The heat which reaches the calorimeter due to imperfect jacketing being o.00I 4 calories per second per degree difference of temperature, a maximum of 3 calories might be introduced under the most unfavorable conditions, which is to be compared with the 30000 to 40000 calories required to melt the ice.

Thermometer Current (5).-The average current employed was 4.5 milliamperes and the thermometer resistance was about 27 ohms, so that the effect of this supply of energy on the temperature of the calorimeter would be absolutely inappreciable even were the thermometer circuit closed all the time.

Evaporation (9).-The large value of the latent heat of vaporization of water involves an appreciable quantity of energy in the evaporation or condensation of but a few milligrams, and unless the procedure be carefully planned serious error may result. A somewhat extended investigation into the evaporation from and condensation on calorimeter surfaces has been carried out in the laboratories of the Bureau of Standards and will be published in 
a separate communication. From the results, it is sufficient to note here that although the top water surface of the calorimeter remained uncovered, in order that the ice might be introduced quickly and without spilling water, the procedure was such that probably no error in excess of I part in 10000 was introduced.

Electrical Energy ( $\mathrm{r}$ ). - The data for this are collected in the left central portion of the sample record. The process of securing the readings is described on page 242 . By reference to figure 5 it may be seen that the potentiometer readings, corrected for instrumental error by certificate of calibration (Pot. cor. on record sheet) give directly the potential drop across the roo-ohm section of a roooo-ohm volt box, and that across the terminals of a o.I-ohm resistance standard. Correction for the volt-box factor, nominally Ioo, reduces the one set of readings to the actual voltage across the terminals of the heating coil in the calorimeter. Correction for the exact resistance of the o.I-ohm standard reduces the other set to the current in amperes through the standard. This is the sum of the currents in the heater (Io ohms) and the volt box (roooo ohms) and the volt-box current, approximately o.oor part of the whole, must be subtracted so as to get the current in the heating coil.

The product of the average value of the current and the emf during the period of heating is labeled "power." The quotient, the resistance of the heater coil, furnishes a valuable check against certain errors. The time factor, obtained from automatic chronograph record explained on page 243 , is multiplied by the power and the product marked "energy." The unit is the joule. ${ }^{18}$

At this point it is necessary to introduce the value of the mechanical equivalent of heat. After careful consideration of the published values and of a considerable amount of work done in this same calorimeter at the Bureau of Standards, but not yet published, the authors have used the value 4.187 international joules equal to one $15^{\circ} \mathrm{cal}^{19}$

\footnotetext{
18 See footnote ro on p. 23 .

19 Some modification of the results announced in this paper will be necessary if conclusive evidence shall later indicate a value of " $J$ " different from 4.187 , but it seems very improbable that such change will exceed $I$ part in 2000 .
} 
Radiation and Convection from Jacket (2).-During the period that the ice was melting the temperature difference between the calorimeter and jacket was directly indicated by a thermoelement. The readings every half minute (zero setting 15 ) show that the calorimeter temperature dropped steadily below that of the jacket (see Fig. 9) to a point where the galvanometer deflection was 7.8 $\mathrm{cm}$, equivalent to $\mathrm{I} . \mathrm{I}^{\circ}$, held steady for about a minute, and then recovered steadily to the jacket temperature. The average deviation, the time and the cooling constant ${ }^{20}$ of the calorimeter

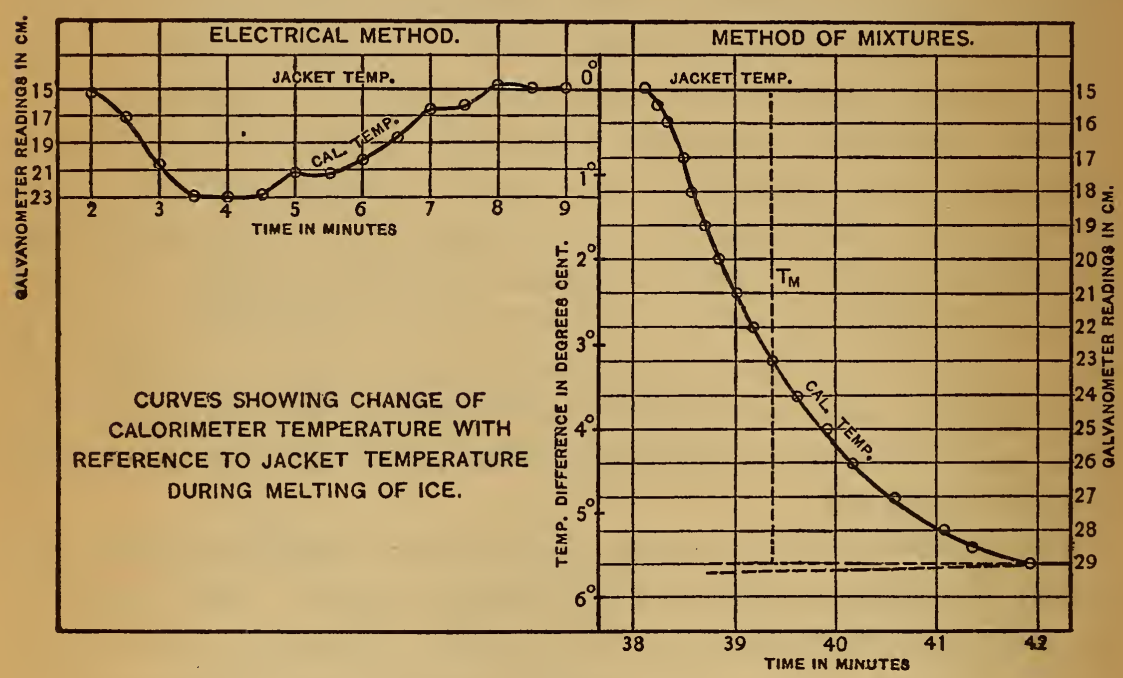

Fig. 9

are set forth in order, and show the method of computing the quantity of heat involved in this correction.

Stirring (3).-The stirring was very constant as shown by the parabolic speed indicator mentioned before, and the power supply of $0.05 \mathrm{I}$ watts at the speed employed has been measured many times during the use of the calorimeter. This figure is equivalent to 0.73 calories per minute. The rest of the computation on the sheet requires no further explanation.

Heating of Calorimeter (8).--Any excess of energy above that absorbed by the ice and its holder will serve to raise the temperature of the calorimeter and a deficiency will be supplied by the 
lowering of this temperature. The quantity of heat so involved is obtained from the product of the heat capacity of the calorimeter (without the ice) by the temperature change.

The heat capacity, including the water and the metal parts of the calorimeter, was determined in other experiments to an accuracy of a few parts in 1000o, but an accuracy of one in a thousand is more than ample for the largest value of this correction term, and figures are therefore rounded off to convenient values.

The temperature change of the calorimeter is determined from the readings $R_{1 \text { cor., }} R_{2}$ cor. In the example, $R_{2}$ cor. $-R_{1}$ cor. equals $0.00756 \mathrm{ohms}$. For thermometer 4727 , 0.I ohm is about a degree, or more exactly, I ohm equals I0:0459 at mean $R$ of 26.687 ohms. ${ }^{21}$

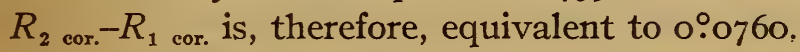

Result of an Experiment (6). - The processes tabulated on pages 25I , 254 may be collected in the following statement: The electrical energy, plus that received from the jacket plus that supplied by stirring, less the amount necessary to raise the temperature of the calorimeter, is the amount of energy which goes into the ice and its holder. The weight of this holder, multiplied by its rise of temperature and its mean specific heat, gives the heat absorbed by the holder (7). The remainder of the heat, divided by the mass of ice, gives a value for the total heat of I gram from the initial temperature of the ice to the final calorimeter temperature $\left(R_{2}\right.$ cor. $)$. The total heat of I gram of water from $0^{\circ}$ to the temperature $R_{2}$ cor. (in terms of the $15^{\circ}$ calorie) is computed from the results of Professor Callendar's ${ }^{22}$ recent work.

Should the values given by Callendar be in error to the extent of I part in rooo, it would affect the results of this paper by about I part in 4000 .

The heat required to change I gram of ice at an initial temperature below $0^{\circ}$ to water at $0^{\circ}$ can not be reduced to give a value for the latent heat of fusion of ice without a knowledge of the specific heat of ice. The discrepancies found in existing data on this constant are so great as to render it very desirable that an early redetermination be made with suitable apparatus and methods, and the Bureau is now engaged in doing this.

${ }^{21}$ Reduction by method described in paper cited in footnote $\mathrm{x}$, p. 242 .

22 Phil. Trans. Royal Society, London, 212A, p. 1; 1912. 
For the determinations at $-0: 72$ an approximate value of the specific heat of ice will suffice. The figure $0.5^{2}$ is here used. An error of 4 per cent in this constant affects the result by about I part in 4000 . For the determinations at $-3^{\circ} \cdot 78$, an error of 4 per cent in the assumed value of $0: 52$ will affect the result to the extent of $\mathrm{I}$ part in 1000.

\section{METHOD OF MIXTURES}

In this method most of the heat required to melt the ice and raise the temperature of the resulting water to the final calorimeter temperature comes from the cooling of the water originally in the calorimeter. Therefore the amount of cooling and the heat capacity of the system require exact determination, while all the other terms entering the computation are relatively small and permit of more or less approximation. The cooling correction is very much larger than in the electrical method, being I to 2 per cent of the total heat measured.

A sample laboratory record of an experiment by this method forms Fig. Io. It is similar to Fig. 8, the notation employed is the same, and the general method of making reductions differs only in so far as different magnitudes for the terms make this necessary. The selections of times $t_{1}$ and $t_{2}$ and the fixing of the corresponding temperatures as measured by resistances $R_{1}$ and $R_{2}$, follow exactly the description of p. $25 \mathrm{I}$ which need not be repeated here.

Between the times $t_{1}$ and $t_{2}$ the same nine processes which are tabulated on pp. $25 \mathrm{I}-254$ occur, except that (I) is missing, and (8) is always a cooling of the calorimeter, the major term of the computation referred to above; (2) and (3) will be discussed together, below. Terms (4) and (5) were negligible, and also (9), the remarks on p. 254 concerning their magnitude applying also to the experiments by the method of mixtures. The calculations involved in paragraphs numbered (6) and (7) are identical in the two methods, so that for the purpose of illustrating the reduction of a method of mixtures experiment it is unnecessary to retain in Fig. Io the complete detail that is shown in Fig. 8, beyond the computation of the total heat absorbed by the ice. 


\section{国prartment of Commore and Tahar \\ BUREAU OF STANDARDS}

谋ăhingutan

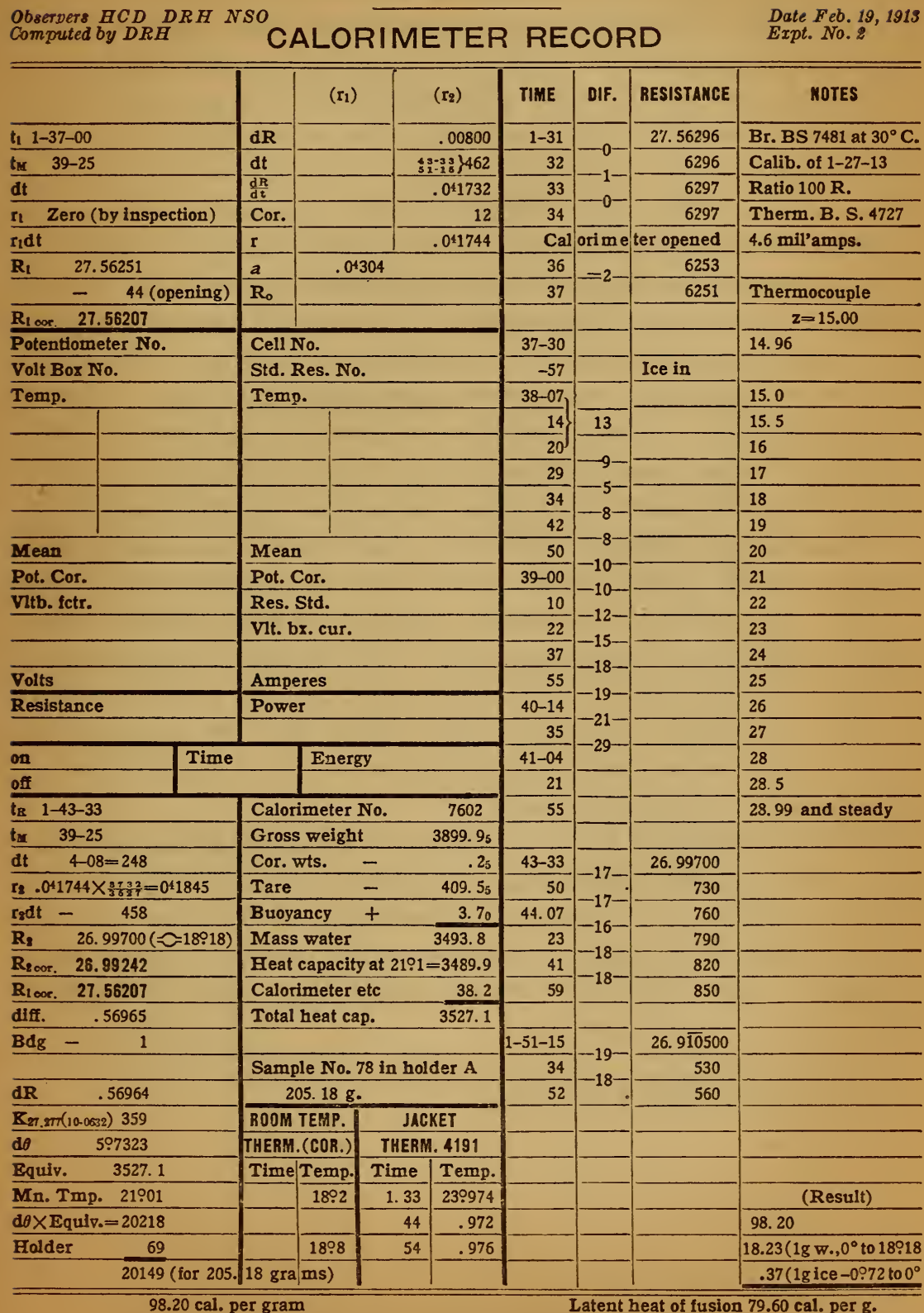

98.20 cal. per gram

Latent heat of fusion 79.60 cal. per $g$.

Fig. 10.-Laboratory record of an experiment by the method of mixtures 
The fundamental equation of the method of mixtures as applied to these experiments may be stated in the following terms: The heat absorbed by the ice and holder is equal to that given up by the calorimeter in cooling plus that received from the jacket by radiation, convection, etc., plus that supplied by the stirrer.

The heat exchange between the jacket and the calorimeter may be computed as a quantity of heat, as was done in reducing the observations by the electrical method, or it may be expressed in terms of the temperature change in the calorimeter which this quantity of heat would cause. When the data upon which the computation is based are obtained by observing rates of rise or fall of the calorimeter temperature, it is usually more convenient to adopt the latter method. A number of methods of making the computation have been devised and might have been followed in this reduction; the one actually employed is described in detail elsewhere. ${ }^{23}$ The computation proceeds with the aid of a mean time, $\left(T_{\mathrm{m}}\right)$, the value of which is dependent on the readings of the temperature difference between calorimeter and jacket during the period $t_{1}$ to $t_{2}$. The details are very easily carried out, but the explanation is somewhat tedious and the reader interested is referred to the paper cited. The result is comprised in the sum of the terms $r_{1} d t$ and $r_{2} d t$ of Fig. Io, $45^{8}$ parts in 57000 for this particular example. (This result may be checked by employing the observation data of the sheet with any method of computing a cooling correction.) "

The large change in the heat capacity of the calorimeter during the course of the experiment, by reason of the introduction of the ice, complicates the process somewhat.

The method of computation automatically corrects for the heat supplied to the calorimeter by the stirrer, provided this supply takes place at a constant rate.

${ }^{23}$ H. C. Dickinson: Combustion Calorimetry and the Heats of Combustion of Sugar, Benzoic Acid, and Naphthalene, to be published In this Bulletin. 
The temperature change ${ }^{24}$ of the calorimeter was computed as follows: The difference of the resistance readings $R_{2}$ and $R_{1}$ was first corrected, by certificate of calibration, for error in the Wheatstone bridge used to measure the resistances. The corrected resistance difference, $\mathrm{d} R$, was then reduced to centigrade temperature difference, $\mathrm{d} \theta$, by employing a factor ${ }^{25}, K$, appertaining to the thermometer used. This factor, 10.0632 in the example, was convenient for slide rule computation, the term 0.56964 being increased by 632 parts per 100000 of itself.

The heat capacity of the calorimeter was determined from the mass of water employed and the heat capacity of the metal parts. Fig. Io shows the mass determination in detail. This mass was multiplied by the ratio of the heat capacity of water at the mean temperature of the experiment to the heat capacity at $15^{\circ}$. The figure employed for the ratio was that given by Callendar. ${ }^{28}$ The heat capacity of the metal parts was computed from the weights recorded when the calorimeter was built and the specific heats. For copper 0.92 was employed for this constant. An error of I per cent in this factor affects the total heat capacity of the calorimeter to the extent of I part in roooo.

24 The scale of temperature $(t)$ to which these measurements are referred is related to the so-called platinum temperature

by the equation

$$
P_{\mathrm{s}}={\frac{R_{\mathrm{t}}-R_{\mathrm{0}}}{R_{100}-R_{0}}}^{100}
$$

$$
t-P_{\mathrm{t}}=1.48\left(\frac{t}{100}-\mathrm{I}\right) \frac{t}{100}
$$

The thermometric scale thus defined is in agreement with the International Hydrogen Scale, from which the constants were indirectly determined as explained in this Bulletin, 3., p. 44I; 1907, to the accuracy with which this scale has been reproduced at the Bureau of Standards (Bulletin 3., p. 663). However, the scale here used is more accurately reproducible than is the International Hydrogen Scale, by the use of the above formulas, applied to thermometers of equally pure platinum.

Thermometers made with this platinum have the following characteristics: Coefficient $\frac{R_{100}-R_{0}}{R_{0}}=0.39 \mathrm{I}$ to 0.392 and the constant ( 1.48 in the foregoing equations) equals about 1.49 when determined from observations in ice, steam and sulphur vapor $\left(444.5{ }^{\circ} \mathrm{C}\right.$.).

25 See footnote 21 on p. 257 .

${ }^{26}$ See footnote 22 on p. 257 . 


\section{RESULTS}

All together the heat of fusion of 92 individual ice samples has been determined by one of the two methods. Of these, the first 50 determinations were made on samples cooled in cryostats antedating those described in this paper, in which the temperatures and the distribution of temperature were not so well known. These observations, which include commercial plate, can, and natural ice as well as ice frozen in the laboratory from doubledistilled water both free from air and containing air, showed no differences greater than one part in a thousand in the heat of fusion for these various samples. However, on account of the uncertainty in the initial temperature of the ice, these earlier determinations are entitled to little or no weight in fixing the absolute value of the latent heat of fusion of ice. The results are therefore omitted from this paper.

Four observations on samples of ice artificially contaminated with a mixture of equal parts of ammonia, sodium chloride, and calcium chloride, to the extent of about one part in a thousand, gave results about I.4 per cent lower than for pure ice.

Of the remaining observations, summarized in Tables 3,4 , and 5 , I4 were made with specimens cooled to $-3^{\circ} \cdot 78$, thus bringing in a considerable uncertainty because of the lack of accurate information as to the specific heat of ice. A comparison of these results with those on samples cooled to $-0^{\circ} .72$ serves to give an approximate value for this constant, and the results can hardly be considered as of value other than for such comparison until more accurate determinations of the specific heat of ice are available for their reduction.

The mean of 12 observations by the electrical method on specimens initially at $-3^{\circ} .78$ is $8 \mathrm{I} .6 \mathrm{I}$, for the total heat from $-3^{\circ} .78$ to water at $0^{\circ}$. Similarly, the mean of 15 observations by the same method on samples initially at $-0^{\circ} .72$ is 80.02 . A comparison of these figures gives for the specific heat of ice 0.520 , a value which is in good agreement with the number previously selected as representing the most probable value of this constant. This value is taken for reducing the results of the $2 \mathrm{I}$ observations upon which is based the final value of the heat of fusion. 
The results which are given in Tables 3,4 , and 5 may be summarized as follows: ${ }^{27}$

\section{TABLE 3}

Summary of Experiments by Electrical Method (Ice at -0:72)

\begin{tabular}{|c|c|c|c|c|c|c|c|c|c|c|c|c|}
\hline Date & $\begin{array}{l}\text { Sample } \\
\text { and } \\
\text { source }\end{array}$ & $\underset{\substack{\text { Ice } \\
\text { (grams) }}}{\text { Mass }}$ & $\begin{array}{c}\text { Elect. } \\
\text { Energy } \\
\div 4.187\end{array}$ & $\underset{\text { (cal.) }}{\mathbf{M} \times \mathbf{d} \theta}$ & $\begin{array}{l}\text { Cool- } \\
\text { ing } \\
\text { cor. } \\
\text { (cal.) }\end{array}$ & $\begin{array}{l}\text { Stir. } \\
\text { (cal.) }\end{array}$ & $\begin{array}{l}\text { Folder } \\
\text { (cal.15) }\end{array}$ & $\begin{array}{c}\text { Ice, } \\
-0: 72 \text { to } \\
\text { Water, } \\
\theta_{2}\end{array}$ & $\begin{array}{c}\text { Final } \\
\text { cal. } \\
\text { Temp. } \\
\theta_{2}\end{array}$ & $\left|\begin{array}{c}\text { Water } \\
0^{\circ} \text { to } \theta_{2} \\
\left(\mathrm{cal}_{15}\right)\end{array}\right|$ & $\begin{array}{c}\text { Ice, } \\
-0.72 \text { to } \\
\text { Water } \\
0^{\circ}\end{array}$ & $\underset{\text { Heat }}{\text { Hatent }}$ \\
\hline 1913. & & & & & & & & & & & & \\
\hline \multirow[t]{5}{*}{ Feb. 13} & 66 Plate & 409 & 39160 & -255 & 25 & 7 & 55 & 95.15 & $15 ? 12$ & 15.17 & 79.98 & 79.61 \\
\hline & 67 Plate & 428 & 39964 & 701 & 48 & 8 & 57 & 94.92 & $14: 83$ & 14.88 & 80.04 & 79.67 \\
\hline & 68 Plate & 443 & 41417 & 551 & 26 & 7 & 56 & 94.67 & $14: 60$ & 14.65 & 80.02 & 79.65 \\
\hline & 69 Plate & 321 & 34194 & -3355 & -27 & 8 & 55 & 95.88 & $15: 79$ & 15.84 & 80.04 & 79.67 \\
\hline & 70 Plate & 369 & 34597 & 788 & 6 & 7 & 52 & 95.67 & $15: 59$ & 15.64 & 80.03 & 79.66 \\
\hline \multirow[t]{3}{*}{ Feb. 14} & 71 Can & 397 & 38082 & -323 & 22 & 6 & 57 & 94.97 & $14: 89$ & 14.94 & 80.03 & 79.66 \\
\hline & 72 Can & 453 & 42363 & 689 & 14 & 7 & 57 & 94.96 & $14: 87$ & 14.92 & 80.04 & 79.67 \\
\hline & 73 Can & 275 & 25565 & 620 & 0 & 6 & 50 & 94.98 & $14: 96$ & 15.01 & 79.97 & 79.60 \\
\hline Feb. 19 & 79 Can & 202 & 21065 & 28 & 11 & 6 & 82 & 103.91 & $23: 81$ & 23.86 & 80.05 & 79.68 \\
\hline Feb. 20 & 82 Can & 213 & 22111 & 87 & 19 & 5 & 72 & 103.75 & $23 \div 67$ & 23.72 & 80.03 & 79.66 \\
\hline \multirow[t]{5}{*}{ Mar. 29} & 94 Natrl & 536 & 51072 & 136 & 74 & 10 & 58 & 95.59 & $15 ? 19$ & 15.24 & 80.35 & reject \\
\hline & 95 Natrl & 512 & 45846 & 987 & 27 & 9 & 58 & 91.42 & $15: 08$ & 15.13 & 76.29 & reject \\
\hline & 96 Natrl & 394 & 37734 & -19 & -1 & 9 & 52 & 95.60 & $15: 53$ & 15.58 & 80.02 & 79.65 \\
\hline & 97 Natrl & 398 & 38071 & 94 & -15 & 9 & 55 & 95.81 & $15: 76$ & 15.81 & 80.00 & 79.63 \\
\hline & 98 Natrl & 489 & 45668 & 1185 & 28 & 9 & 57 & 95.72 & 15965 & 15.70 & 80.02 & 79.65 \\
\hline
\end{tabular}

Mean 79.65

TABLE 4

Summary of Experiments by Method of Mixtures (Ice at $-0^{\circ} 72$ )

\begin{tabular}{|c|c|c|c|c|c|c|c|c|c|c|}
\hline Date & $\begin{array}{l}\text { Sample } \\
\text { and } \\
\text { source }\end{array}$ & $\begin{array}{c}\text { Mass } \\
\text { Ice } \\
\text { (grams) }\end{array}$ & $\mathbf{d} \theta$ & $\underset{\text { (cal.) }}{\mathbf{M} \times \mathbf{d} \theta}$ & $\begin{array}{l}\text { Holder } \\
\text { (cal.) }\end{array}$ & $\begin{array}{c}\text { Ice, } \\
-0.72 \text { to } \\
\text { water, } \theta_{2}\end{array}$ & $\begin{array}{l}\text { Final cal. } \\
\text { Temp. } \theta_{2}\end{array}$ & $\begin{array}{c}\text { Water } \\
0 \text { ? to } \theta_{2} \\
\left.\text { (cal }{ }_{15}\right)\end{array}$ & $\begin{array}{c}\text { Ice, } \\
-0972 \text { to } \\
\text { Water, } 0^{\circ}\end{array}$ & $\begin{array}{c}\text { Latent } \\
\text { Heat } \\
\left(15^{\circ} \text { cal. }\right)\end{array}$ \\
\hline 1913 & & & & & & & & . & & \\
\hline \multirow{3}{*}{ Feb. 14} & 74 Can & 122 & $3: 1100$ & 11301 & 42 & 92.09 & $12: 02$ & 12.07 & 80.02 & 79.65 \\
\hline & 75 Can & 129 & 394470 & 12509 & 54 & 96.56 & $16: 57$ & 16.62 & 79.94 & 79.57 \\
\hline & 76 Can & 110 & 299463 & 10691 & 52 & 97.05 & 17902 & 17.07 & 79.98 & 79.61 \\
\hline \multirow{3}{*}{ Feb. 19} & 77 Can & 216 & 599941 & 21145 & 67 & 97.49 & $17: 47$ & 17.52 & 79.97 & 79.60 \\
\hline & 78 Can & 205 & 597323 & 20218 & 69 & 98.20 & $18 ? 18$ & 18.23 & 79.97 & 79.60 \\
\hline & 80 Can & 188 & $5: 2813$ & 18628 & 60 & 98.51 & $18: 43$ & 18.48 & 80.03 & 79.66 \\
\hline \multirow[t]{2}{*}{ Feb. 20} & 81 Can & 207 & 597587 & 20312 & 62 & 97.88 & $17: 88$ & 17.93 & 79.95 & 79.58 \\
\hline & 83 Can & 190 & $5: 3010$ & 18698 & 60 & 98.21 & $18: 19$ & 18.24 & 79.97 & 79.60 \\
\hline
\end{tabular}

27 The material retained in these tables has been selected with two purposes in view: (r) To show the order in which experiments by different methods were carried out, the variation in quantities of ice used, and the values of the principal term and its correction terms; (2) to give complete data necessary to recomputation on the basis of different values for the mechanical equivalent of heat, the specific heat of water and total heat from $0^{\circ}$ to various temperatures, and the specific heat of ice. 
TABLE 5

Summary of Experiments by Electrical Method (Ice at -3:78)

\begin{tabular}{|c|c|c|c|c|c|c|c|c|c|c|c|c|}
\hline Date & $\begin{array}{l}\text { Sample } \\
\text { and } \\
\text { source }\end{array}$ & $\left|\begin{array}{c}\text { Mass } \\
\text { Ife } \\
\text { (grams) }\end{array}\right|$ & $\begin{array}{l}\text { Elect. } \\
\text { Energy } \\
\div 4.187\end{array}$ & $\underset{(\text { cal. })}{\mathbf{M} \times \mathbf{d} \theta}$ & $\begin{array}{c}\text { Cool- } \\
\text { ing } \\
\text { cor. } \\
\text { (cai.) }\end{array}$ & $\begin{array}{c}\text { Stirrer } \\
\text { (cal.) }\end{array}$ & \begin{tabular}{|} 
Holder \\
(cal.)
\end{tabular} & $\begin{array}{c}\text { Ice, } \\
\text { 3078 to } \\
\text { Water, } \\
\theta_{2}\end{array}$ & $\begin{array}{c}\text { Tinal } \\
\text { cal. } \\
\text { Temp. } \\
\theta_{2}\end{array}$ & $\left|\begin{array}{c}\text { Water } \\
0^{\circ} \text { to } \theta_{2} \\
\left(\mathrm{cal}_{15}\right)\end{array}\right|$ & $\begin{array}{c}\text { Ice, } \\
\text {-3978 to } \\
\text { Water, } \\
0^{\circ}\end{array}$ & $\begin{array}{l}\text { La- } \\
\text { tent } \\
\text { Heat } \\
\left(15^{\circ}\right. \\
\text { cal. })\end{array}$ \\
\hline 1913 & & & & & & & & & & & & \\
\hline \multirow[t]{4}{*}{ Feb. 5} & 51 Can & 546 & 52993 & -94 & 87 & 10 & 67 & 97.00 & 15936 & 15.41 & 81.59 & \\
\hline & 53 Can & 506 & 48718 & 99 & 47 & 10 & 71 & 96.49 & 14981 & 14.86 & 81.63 & ก่ \\
\hline & $54 \mathrm{Can}$ & 382 & 36516 & 386 & 41 & 8 & 59 & 96.54 & 14988 & 14.93 & 81.61 & 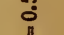 \\
\hline & 55 Can & 377 & 36503 & 4 & 39 & 8 & 63 & 96.75 & $15: 09$ & 15.14 & 81.61 & 范 \\
\hline \multirow[t]{5}{*}{ Feb. 6} & 56 Can & 487 & 47753 & -288 & 71 & 10 & 72 & 97.50 & 15986 & 15.91 & 81.59 & $\overline{0}$ \\
\hline & $57 \mathrm{Can}$ & 491 & 47311 & 36 & 41 & 10 & 68 & 96.45 & $14: 80$ & 14.85 & 81.60 & $\ddot{\tilde{\pi}}$ \\
\hline & 58 Can & 315 & 30189 & 245 & 28 & 7 & 62 & 96.47 & 14981 & 14.86 & 81.61 & \\
\hline & 59 Can & 470 & 45590 & -173 & 4 & 9 & 65 & 96.60 & 14990 & 14.95 & 81.65 & ฐ \\
\hline & $60 \mathrm{Can}$ & 313 & 30360 & -64 & 12 & 8 & 59 & 96.61 & 14993 & 14.98 & 81.63 & 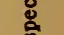 \\
\hline \multirow[t]{4}{*}{ Feb. 7} & 61 Can & 484 & 46817 & -90 & 24 & 10 & 68 & 96.46 & $14: 82$ & 14.87 & 81.59 & $\approx$ \\
\hline & $62 \mathrm{Can}$ & 482 & 46237 & 286 & 35 & 11 & 68 & 96.43 & $14: 76$ & 14.81 & 81.62 & \\
\hline & $65 \mathrm{Can}$ & 365 & 35224 & 22 & 211 & 91 & 59 ! & 96.35 & 14971 & 14.76 | & 81.59 & \\
\hline & & & & & & & & & \multicolumn{3}{|c|}{$\begin{array}{r}\text { Mean 81.61 } \\
0.52 \times 3.78=1.96\end{array}$} & \\
\hline
\end{tabular}

I. Five observations, by the electrical method, on samples of commercial plate ice, give for the heat of fusion $79.65 \mathrm{cal}_{15}$ per gram mass, with a mean variation of 0.02 calorie.

2. Five observations, by the electrical method, on commercial can ice give $79.65 \mathrm{cal}_{15}$ per gram mass, with a mean deviation of 0.02 calorie.

3. Eight observations, by the method of mixtures, on commercial can ice give 79.6 cal. $_{15}$ per gram mass, with a mean deviation of 0.02 calorie.

4. Five observations, by the electrical method, on Maine natural ice were made, of which three are consistent with each other and with other results while two (Mar. 29, Nos. 94 and 95) are so discordant and differ so much from other results as to justify their omission. The three determinations give $79.64 \mathrm{cal}_{{ }_{15}}$ per gram mass, with a mean deviation of o.or calorie. 
The mean of results by the electrical method is

$$
79.65 \mathrm{cal}_{15}
$$

if the ratio of the calorie $e_{15}$ to the joule be taken as 4.I87.

The mean of results by the method of mixtures is

$$
79.6 \mathrm{I} \mathrm{cal}_{15}
$$

independently of the ratio of the joule to the calorie.

The mean of the 2 I observations gives for the heat of fusion of ice

$$
\begin{aligned}
79.63 \mathrm{cal}_{15} & \text { per gram mass } \\
& \text { or } \\
143.3{ }_{3} \mathrm{Btu}^{28} & \text { per pound mass } \\
& \text { or }
\end{aligned}
$$

approximately 143.5 Btu per pound weighed in air against brass or iron weights.

\section{SUMMARY}

The work of previous investigations is briefly reviewed and the results tabulated.

The apparatus and procedure of the present investigation are fully described.

Samples of ice prepared in the form of hollow cylinders containing from 100 to 500 grams were cooled to a uniform temperature of either $-0^{\circ} .72$ or $-3^{\circ} .78$, weighed while at these temperatures, and introduced into the water of the calorimeter.

Observations were made by two independent methods, one of which, an electrical method, serves to reduce the usual calorimetric corrections to an almost negligible quantity and gives the results primarily in terms of the joule as defined by the electrical units. The second was the method of mixtures which gives the heat of fusion in calories.

The details of computation for observations taken by each method are given in full.

Results.-The heat of fusion of 92 samples of ice from various sources was determined by the two methods.

${ }^{28}$ The British thermal unit (Btu) is here taken as the quantity of heat required to raise the temperature of a pound mass of water $\mathrm{I}^{\circ} \mathrm{F}$ at $59^{\circ} \mathrm{F}\left(15^{\circ} \mathrm{C}\right)$. 
The results of these determinations indicate that for commercial can ice, commercial plate ice, natural ice, ice frozen in the laboratory from air-free double-distilled water and from double-distilled water containing air, all of which were very pure as indicated by electrical conductivity tests, the heat of fusion is the same to within the limits of accuracy of the earlier determinations, i. e., about I part in 1000. Further experiments on the three commercial forms of ice fail to show differences greater than about I part in 5000 .

Five observations on ice contaminated with a mixture of ammonia, sodium chloride, and calcium chloride to the extent of about I part in IOoO give results about I.4 per cent lower than for pure ice.

The mean of the final 2 I determinations on samples of plate, can, and natural ice gave for the heat of fusion:

$79.63 \mathrm{cal}_{15}$ per gram mass, or $\mathrm{I} 43.3_{3}$ Btu per pound mass,

or 143.5 Btu per pound weighed in air against brass or iron weights.

Washington, August 20, 1913. 



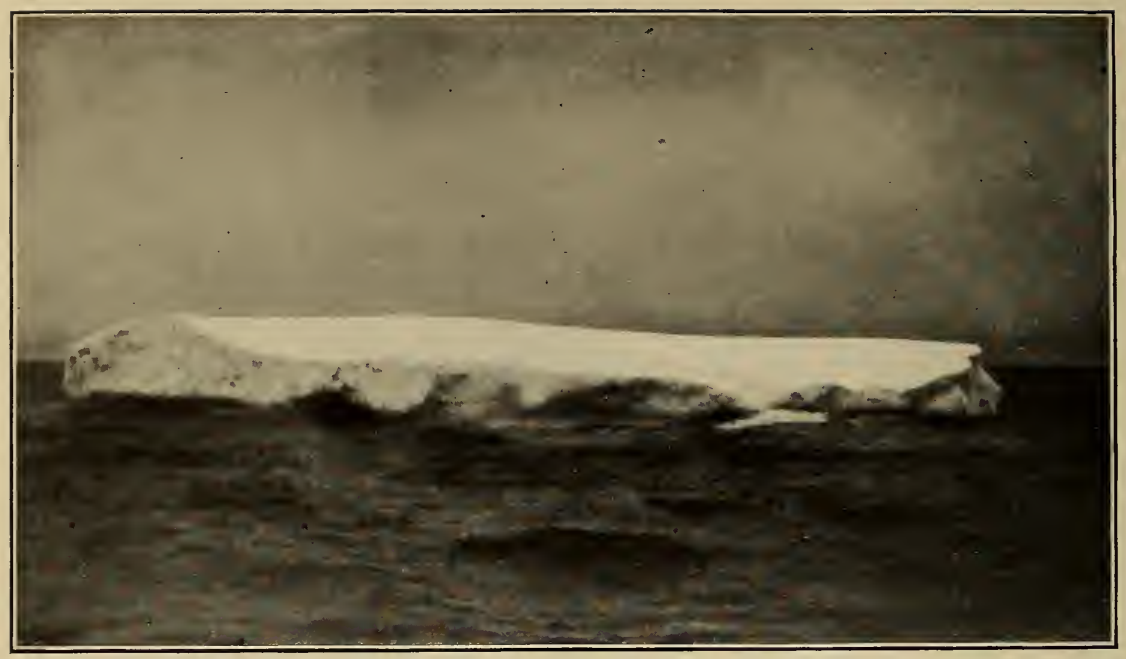

A berg about 40 feet high and 300 feet long. Sighted July 1, 1912

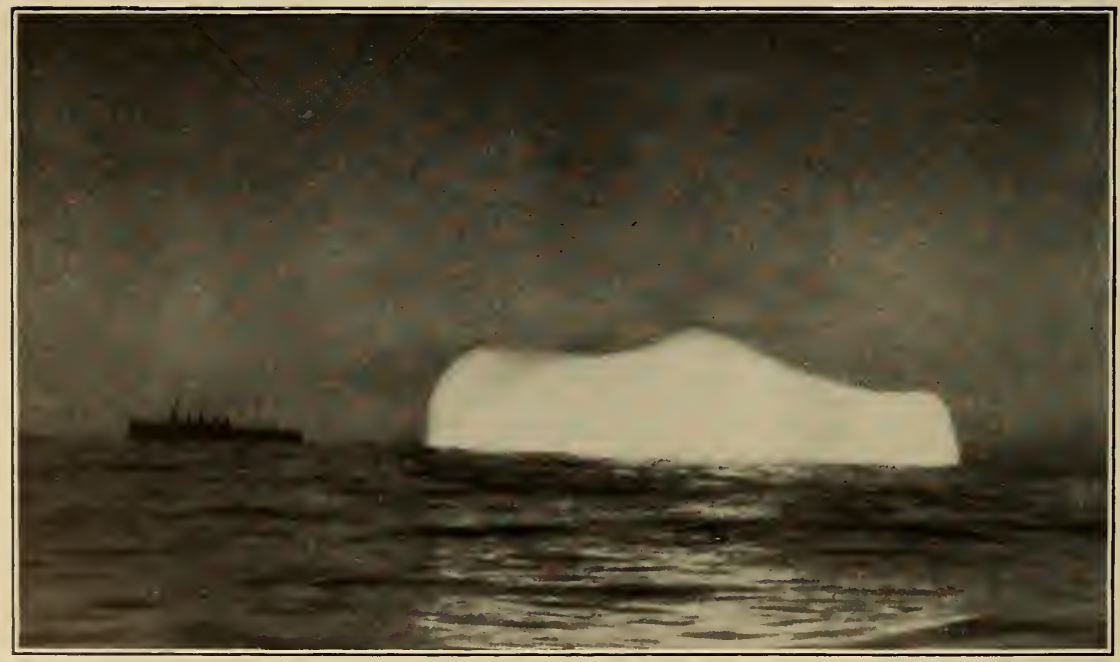

400,000-ton berg with U. S. S. "Chester" in background. Sighted June 17, 1912 



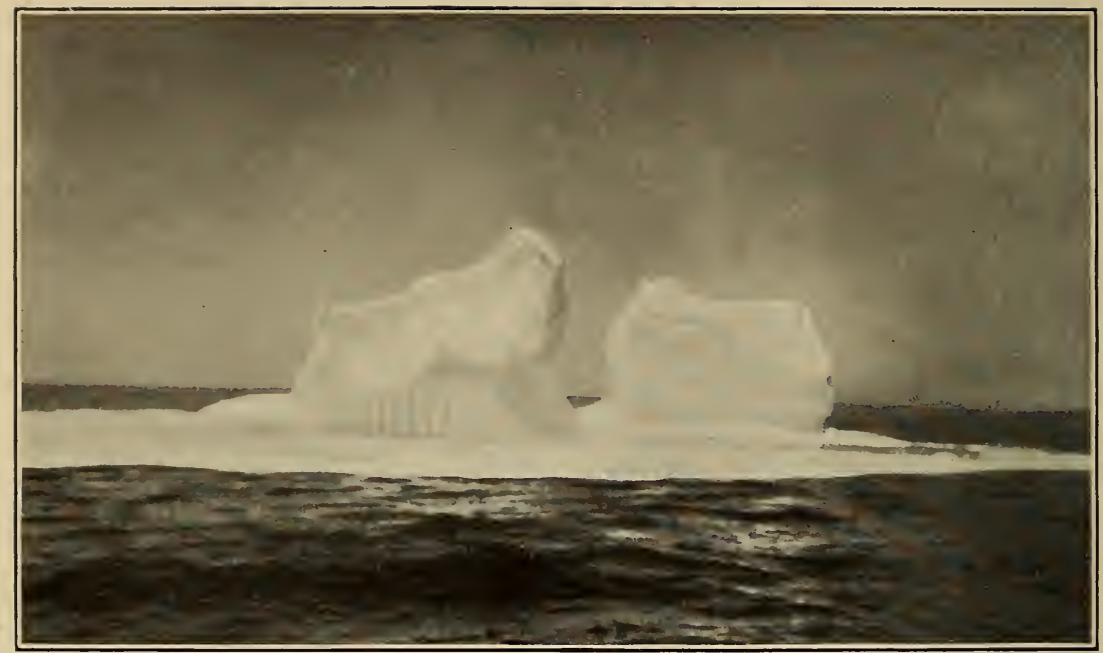

Berg after being struck by three 3-inch shells. Sighted June 23, 1912

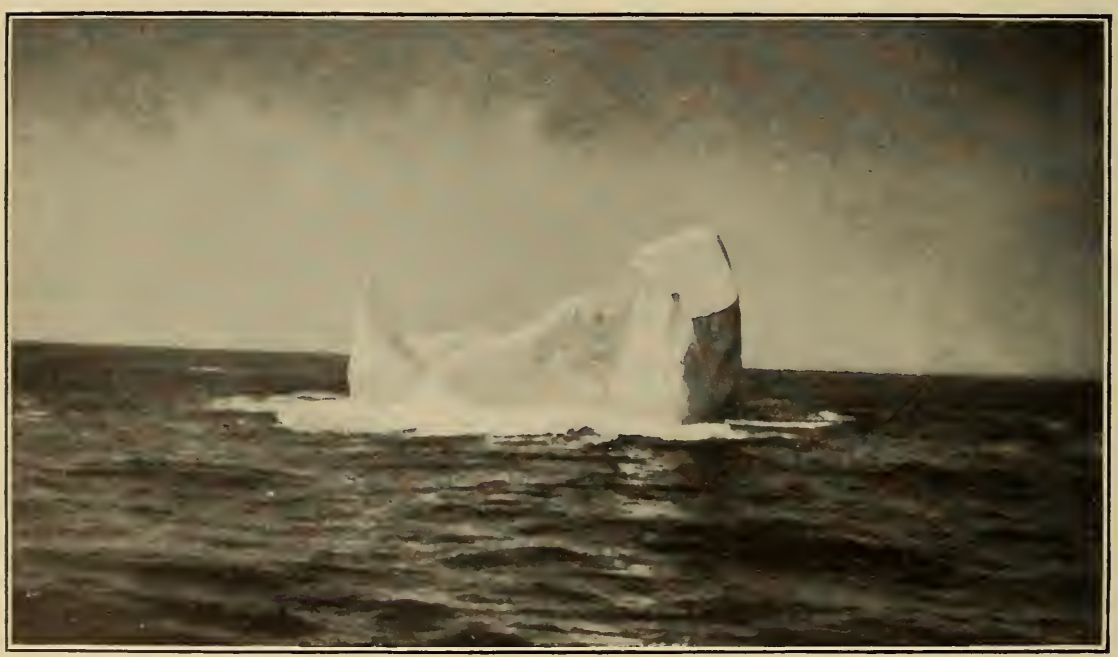

Berg after being struck by a 5-inch shell. Sighted June 23, 1912 



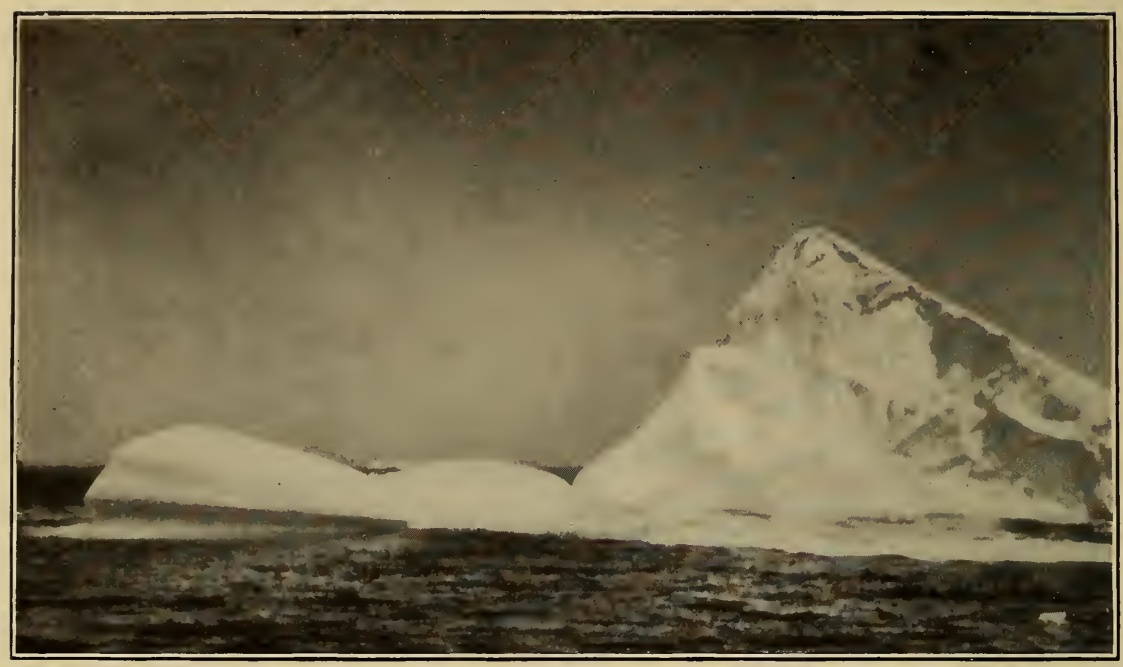

Berg showing a dangerous projection which has just been brought to the surface by the turning of the berg. Sighted July 2, 1912

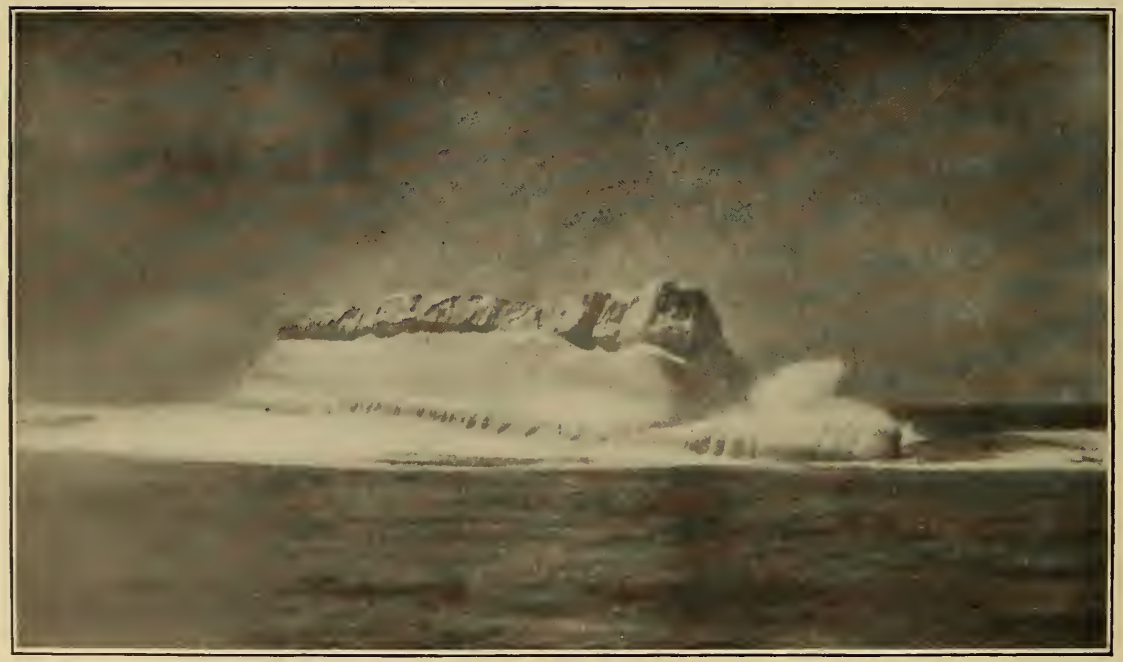

Another view of above showing the original water line. Height about 125 feet 




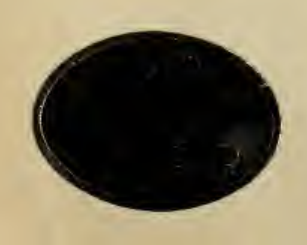


